\title{
Bayonets for the Peabody-Martini Rifle
}

\section{Julian Bennett}

To cite this article: Julian Bennett (2019) Bayonets for the Peabody-Martini Rifle, Arms \& Armour, 16:1, 75-104, DOI: 10.1080/17416124.2019.1581489

To link to this article: https://doi.org/10.1080/17416124.2019.1581489

曲 Published online: 06 Mar 2019.

Submit your article to this journal

Џll Article views: 84

Q View related articles $ᄃ$

View Crossmark data \lceil 
ARMS \& ARMOUR, Vol. 16 No. 1, April 2019, 75-104

\title{
Bayonets for the Peabody-Martini Rifle
}

\author{
JULIAN BENNETT
}

\author{
Department of Archaeology, Ihsan Doğramacı Bilkent University, \\ Ankara, Turkey
}

From its introduction in 1874 until the turn of the nineteenth century the principal infantry firearm of the Ottoman army was the American-made .45 $(11.43 \times 55 \mathrm{R})$ calibre Peabody-Martini Rifle. Remaining in use with secondary units until 1916/1917, three bayonet types were provided for the rifle during its official service life: a quadrilateral cross-sectioned socket form, followed by a yataghan-style sword bayonet, and finally a shortened and straightened version of this same yataghan bayonet. As such these three bayonets provide a classic illustration of bayonet typology for the period. However, their history and characteristics have never been assessed in detail, an omission this article seeks to remedy.

KEYWORDS Peabody-Martini Rifle, Peabody-Martini socket bayonets, PeabodyMartini yataghan bayonets, Providence Tool Company, Martini-Henry Rifle, Turkish Model Mauser Rifles, Plevna

\section{Introduction}

The intent of this article is to provide a detailed assessment as is possible of the three types of bayonets used by the Ottoman Army with its first modern service rifle, that version of the Martini-Henry rifle commonly known as the Peabody-Martini. ${ }^{\mathrm{I}}$ This American-made version takes its name from how it is marked on its left-hand receiver to indicate it combines the falling block and extractor system patented in I 862 by $\mathrm{H}$. O. Peabody and the simpler cocking and firing mechanism patented in I 868 by F. von Martini. ${ }^{2}$ Examples of the bayonets for this rifle are uncommon outside of Turkey in either public or private collections, while the bayonet types themselves have not previously been fully described in the relevant literature. This article intends to fill that void as far as possible by detailing the biographies, as it were, of the three types, and their principal characteristics. We begin this essay, though, with an overview of the Peabody-Martini Rifle itself, a firearm that will be unfamiliar to 


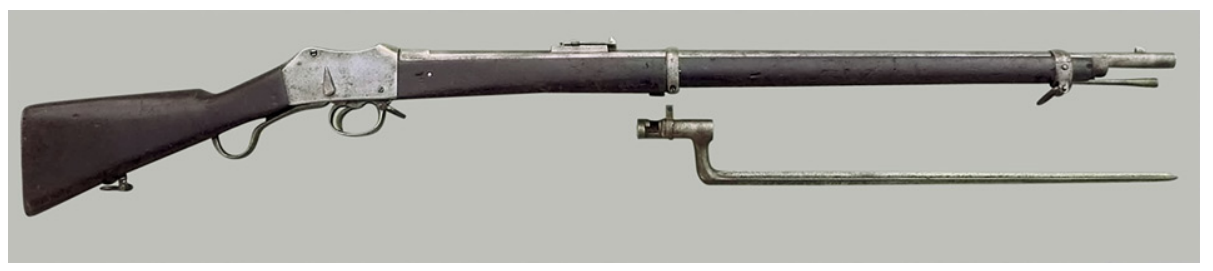

FIGURE 1. An early Peabody-Martini Rifle with its quadrilateral socket bayonet (photograph supplied by Nick Stanev).

many: as bayonets belong to rifles, a summary account of its history, development, and main attributes, is germane to our understanding of its bayonets. ${ }^{3}$

\section{The Peabody-Martini Rifle}

In the early summer of 1872 , Ismael, the Khedive of Egypt, allegedly promised his suzerain, the Ottoman Sultan Abdul-Aziz, '50,000 Martini-Henry rifles already ordered from England', gifting these ' 50,000 Martini-Henry Rifles of the latest pattern' in person at Constantinople shortly after. ${ }^{4}$ Doubt must be cast on the absolute accuracy of the story: the Martini-Henry Rifle was then undergoing service trials with the British army, production of the Mk.I. 'Third Pattern' for general service use not being granted until I October I $874 .{ }^{5}$ Yet as a contest was held in early July I 872 at the Ottoman capital to assign a contract for the production of 200,000 copies of -it will be shown-the Martini-Henry Mk.I 'Second Pattern' Rifle, the Ottoman authorities must have received at least one example of this firearm by then. ${ }^{6}$ The competition was won by the Providence Tool Company of Rhode Island, USA, and on Io July they submitted their offer for a 'Martini-Henry Rifle' at \$16.25 per rifle with a quadrangular sectioned socket bayonet, or \$17.50 with a sword-type bayonet, half the required number being available within six months of receiving a pattern example, the remainder over the following $\mathrm{I} 2$ months with a suitable discount. ${ }^{7}$ The price per rifle with a socket bayonet was acceptable by the Ottoman government, and so the genesis of the Peabody-Martini Rifle. Then, in I 873 two further contracts were agreed between the Providence Tool Company and the Ottoman government for an additional 400,000 Peabody-Martini Rifles, bringing the total of the three orders to $600,000 .^{8}$

These first examples of the Peabody-Martini Rifle and their socket bayonets were not produced until January I 874 (Figure I), 9 mainly owing to a delay in receiving a pattern example of the required weapon. ${ }^{\mathrm{IO}}$ This pattern example was evidently a Martini-Henry Mk.I 'Second Pattern' Rifle as approved for British trials service on the 3 September I87I, for all Peabody-Martini Rifles have the chequered butt stock plate and thumb rest found specifically on that weapon (see, e.g. Figure го). ${ }^{\mathrm{II}}$ The first production examples also have the same safety catch as that version, which, just as with the later Martini-Henry's, was dispensed with on those Peabody-Martini's 


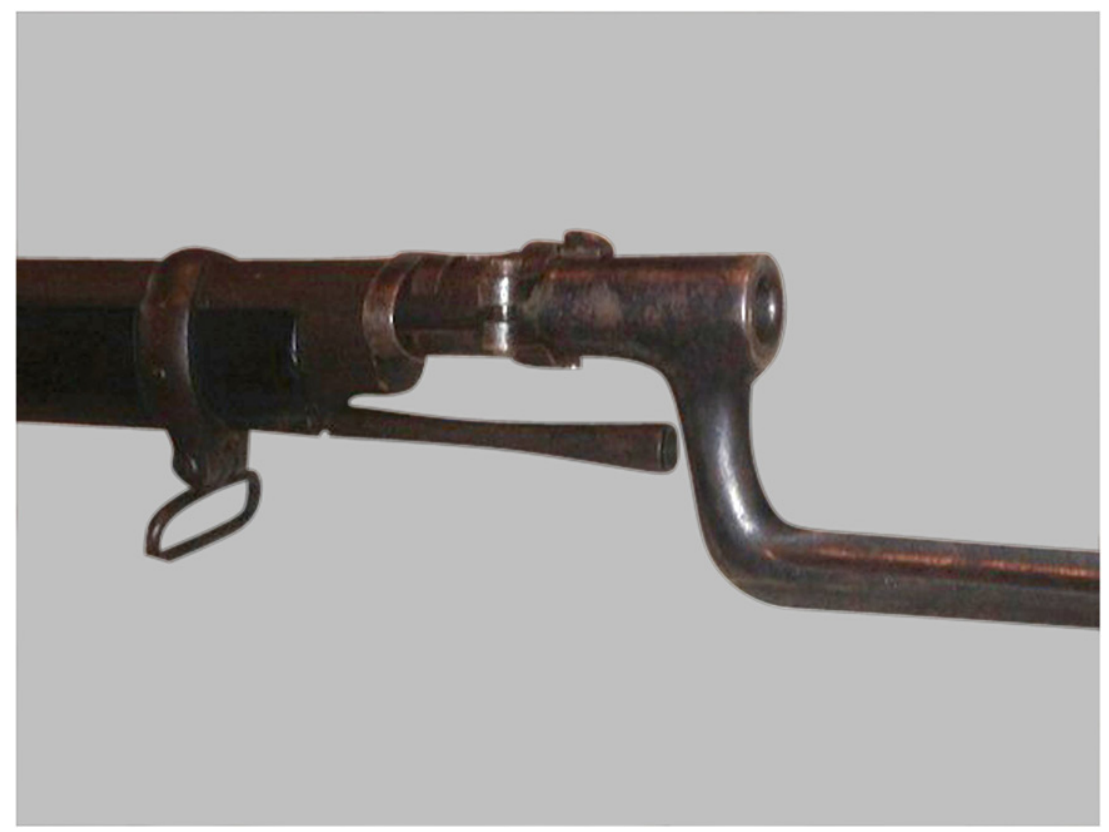

FIGURE 2. Detail of the socket bayonet as fitted to an early Peabody-Martini Rifle (photograph from the John Ward collection).

made after 20 November I 876 . By that time 369,000 rifles had been completed to the original specification, ${ }^{\mathrm{I} 2}$ these now being known to collectors as the 'Type A', those without being classed as 'Type B'. ${ }^{13}$ However, while maintaining the same barrel diameter and 49 inches $(\mathrm{I} 24.5 \mathrm{~cm})$ overall length as the Martini-Henry, the Peabody-Martini Rifle was-as stipulated by Constantinople-chambered for a I I. $43 \times 55$ R Berdan-type cartridge instead of the British $.577-450$ 'Boxer', and fitted with a I 200 metre rear sight graduated in Persian-style numbers. ${ }^{\mathrm{I}}$ Moreover, while the Martini-Henry Mk.I 'Second Pattern' could be fitted with either a socket or a sword-type bayonet, with the blade resting along the right side of the barrel, ${ }^{\mathrm{I} 5}$ all Peabody-Martini Rifles made for the first contract and most for the second took a socket bayonet only fitted below the barrel (e.g. Figure 2). Finally, all PeabodyMartini Rifles were engraved on the right-hand side of the receiver with the tughra or monogram of the reigning Ottoman sultan-Abdül Aziz (I86I-I 876) for the first contract, Murad V (I 876), and Abdülhamid II (I876-I909) for the remainder-and a serial number using Persian-based Turkish numerals, the left-hand side being stamped 'PEABODY \& MARTINI PATENTS [or PATENT]/MAN'FED BY/ PROVIDENCE TOOL CO./PROV.R.I. U.S.A' (Figures 3 and 4).

The first rooo Peabody-Martini Rifles were delivered to Constantinople in March ${ }^{1} 874,{ }^{16}$ a slight change being introduced after January I 875 following an agreement made at that time that the last 200,000 rifles of the total 600,000 eventually commissioned be supplied with yataghan sword bayonets, ${ }^{17}$ requiring a bayonet bar on the 
top barrel band (e.g. Figures 5 and 6). Thus, both versions of the rifle served with the Ottoman army during the I $877-\mathrm{I} 878$ Russo-Turkish War, gaining a reputation for their ruggedness, ${ }^{18}$ the rifle winning its greatest moment of fame at the Siege of Plevna in 1877 , when its effectiveness in decimating attacking Russian infantry ensured the 'Plevna Delay', stalling the Russian advance on Constantinople for over five months. ${ }^{\text {I9 }}$ However, the eventual capture of Plevna and the series of defeats leading up to the Ottoman capitulation in 1878 cost their army dearly, an official inventory of June 1879 reporting the loss of I 56, 277 'Martini-Henry' Rifles in the campaign, along with 207,555 Snider rifles, I I,708 Winchester carbines and 28,527 Winchester rifles. ${ }^{20}$

The last of the 600,000 Peabody-Martini Rifles commissioned from the Providence Tool Company were despatched to Constantinople on 24 December I $880 .{ }^{2 \mathrm{I}}$ It is perhaps no coincidence that by May I $88 \mathrm{I}$, the Tüfekhâne-1 'Âmire, the rifle factory in Constantinople, began producing its own 'Martini-Henry' rifles along with clones of other older rifles used by Ottoman reserve units, ${ }^{22}$ evidently to replace losses incurred during the I $877-\mathrm{I} 878$ War. This programme itself probably came about because of a reluctance if not an outright refusal by the Providence Tool Company - and probably other weapons makers in the USA - to accept any more firearm contracts from Constantinople owing to the habitual repeated delays in paying for commissioned weapons. Certainly, such delays over paying for the 600,000 Peabody-Martini Rifles by the Rhode Island company were a major factor leading to its bankruptcy on I9 April I 882. ${ }^{23}$ And so the Tüfekhâne-1 'Âmire were evidently now forced into a 'reverse-engineering' process to satisfy the requirements of the Ottoman army for its standard infantry rifle.

In I886, all the 'Martini' rifles and other weapons of a similar vintage stocked in Ottoman armouries were officially declared 'obsolete and useless'. ${ }^{24}$ The declaration can be associated with trials for a new service rifle held that same year, ${ }^{25}$ and the decision in February 1887 by Sultan Abdül Hamid to commission the $9.5 \times 60 \mathrm{~mm}$ calibre 'Turkish' Model I 887 rifle as the first of a succession of Mauser-designed rifles for the Ottoman army. ${ }^{26}$ Even so, the Tüfekhâne-1 'Âmire continued making 'Martini' rifles as late as $1890 .{ }^{27}$ Just as well, as the Ottoman High Command proved curiously reluctant to issue its regular never mind its reserve soldiers with the 'Turkish' Model I 887, or its immediate successors, the 'Turkish' Models I890, I 893 and 1903 , which all used the smaller and more powerful $7.65 \times 53 \mathrm{~mm}$ cartridge and smokeless powder. ${ }^{28}$ Thus, 9 out of Io Ottoman divisions in the Graeco-Turkish War of I 897 were armed with the 'obsolete and useless' 'Martini' and older Snider rifles, ${ }^{29}$ while it was not until November 1904 that the 6th (Baghdad) Corps exchanged their 'old Martini rifle, now much worn' from long service, for Mausers. ${ }^{30}$

Despite having received 913,000 Mauser rifles by $1908,{ }^{3 \mathrm{I}}$ in I9I0 the decision was made to extend the service life of the 'obsolete' Peabody-Martini Rifle by converting at least 173,778 to accept the same $7.65 \times 53 \mathrm{R}$ cartridge employed in the 


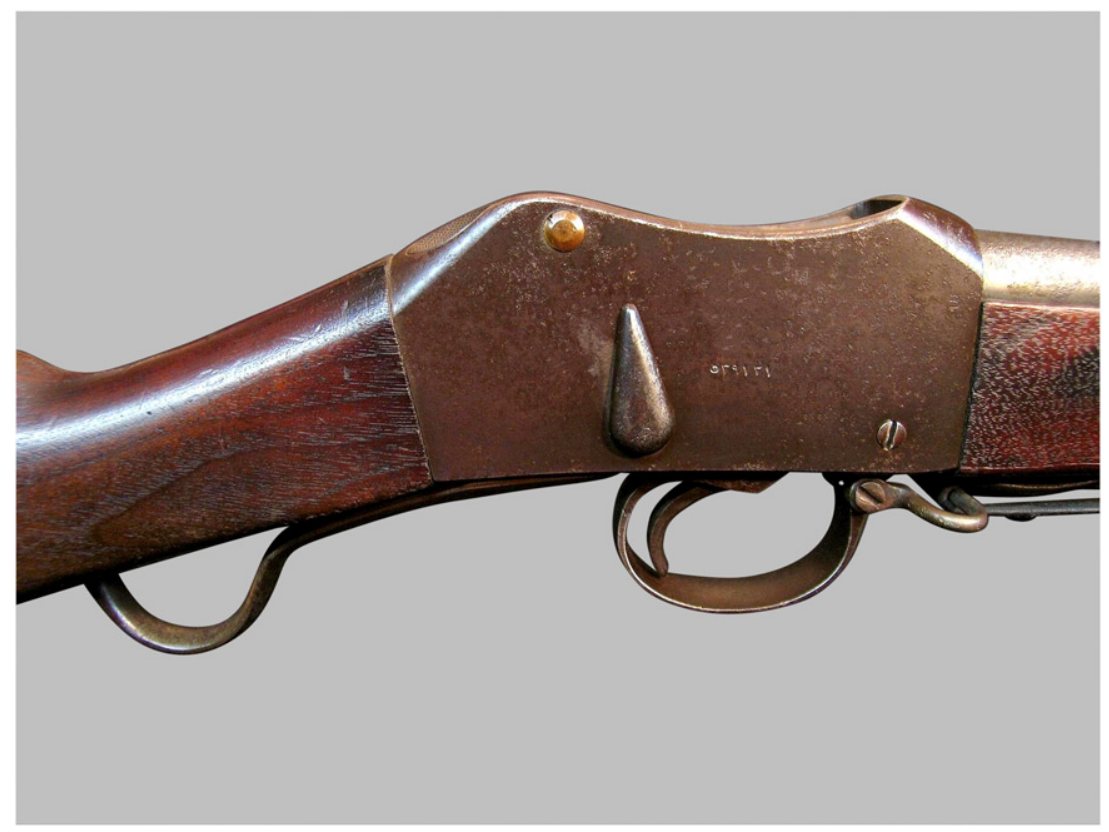

FIGURE 3. Right-hand side of the receiver on an early production Peabody-Martini, showing the tughra and serial number, in this case 539121 (photograph supplied by John P. Sheehan).

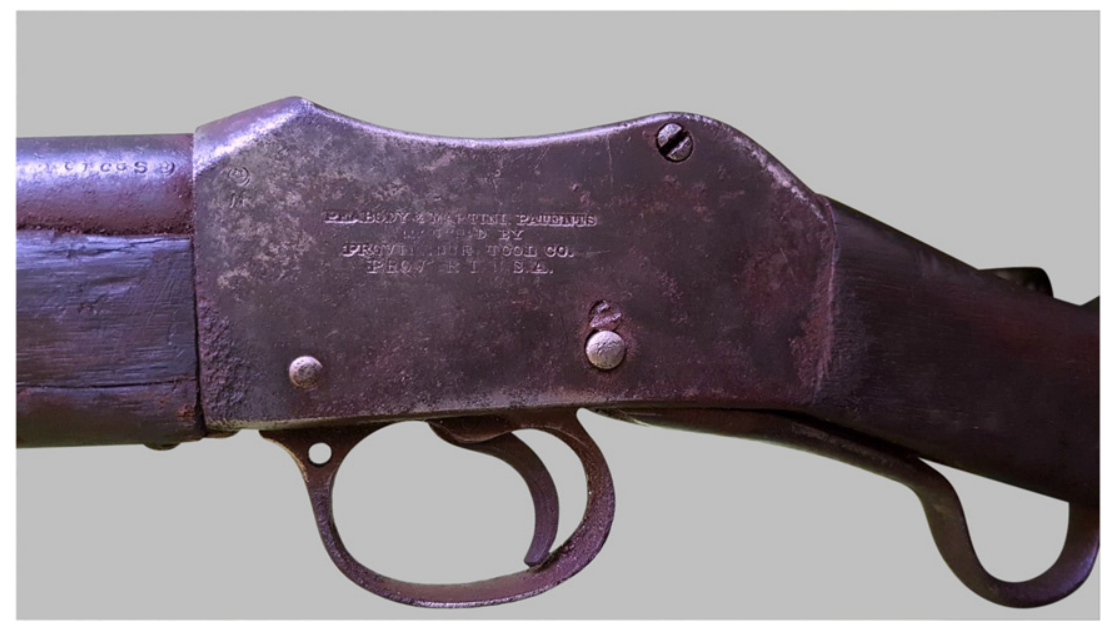

FIGURE 4. Left-hand side of the receiver on an early production Peabody-Martini, showing the makers mark (photograph supplied by Bahadir Saydag).

'Turkish' Model I890, I893 and I903 rifles. $^{32}$ The conversion process involved truncating the original breech blocks for a new extractor and fitting a newly made shorter barrel of around 29.13 inches $(74 \mathrm{~cm})$, these being made between October I9I0 and March I9I I by the Österreichische Waffenfabriks-Gesellschaft at Steyr. ${ }^{33}$ 


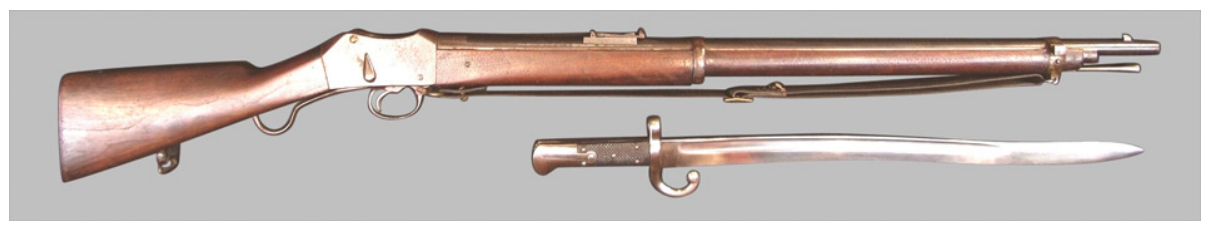

FIGURE 5. A post-1875 Peabody-Martini Rifle with its yataghan bayonet and bayonet lug on the top barrel band (photograph supplied by John P. Sheehan).

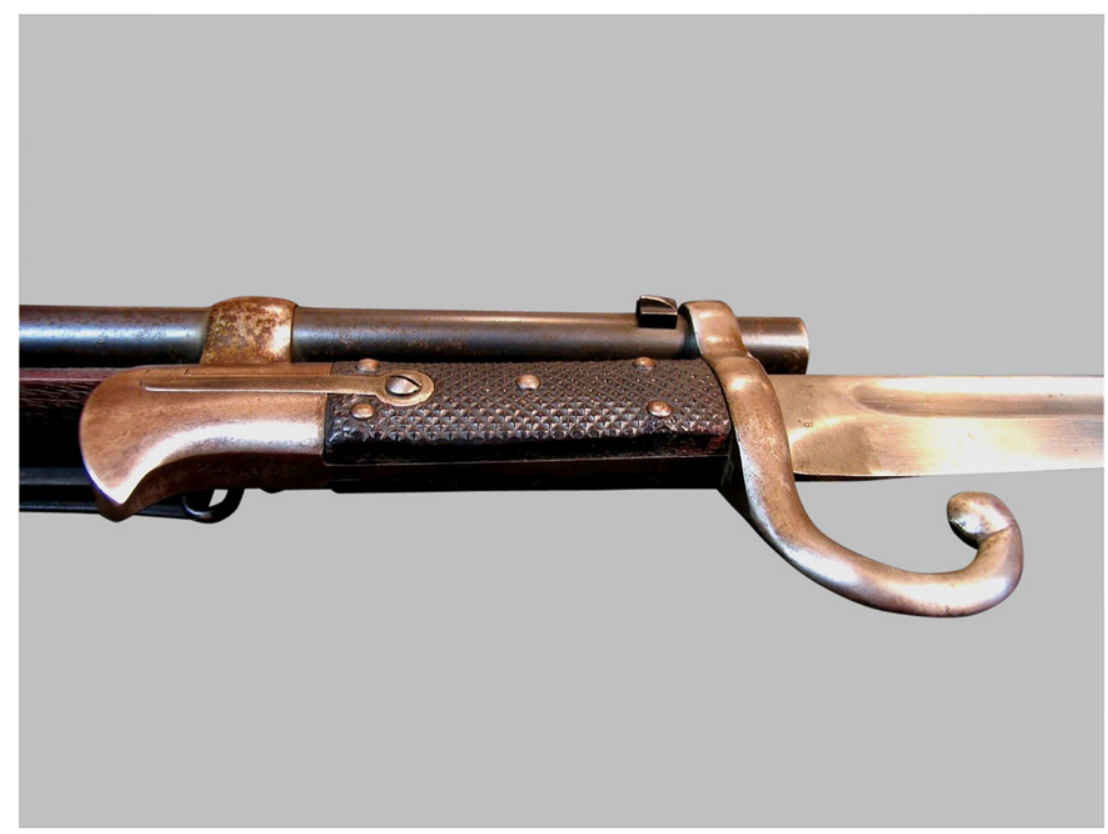

FIGURE 6. Detail of the yataghan bayonet fitting on a post-1875 Peabody-Martini, Rifle (photograph supplied by John P. Sheehan).

The result was a rifle with an overall length of $45 \cdot 5$ inches compared to the 49 inches of the original, the barrel being the same diameter as the original Peabody-Martini Rifle so as to fit the existing stocks of Peabody-Martini socket and sword bayonets. This meant fitting a socket bayonet lug where the foresight on the original rifles was, the new foresight being set slightly back from this above the top barrel band and its bayonet lug. Moreover, as we will see, many of the existing sword bayonets were now shortened to maintain balance (Figures 7 and 8 ). The conversions, which were somewhat heavier at around 9 pounds 4 ounces $(4.20 \mathrm{~kg})$ than the original rifles, were stamped on the left-hand side of the receiver with an Ottoman text beneath the existing Peabody-Martini markings, this reading in translation 'Tüfenk Fabrikası/ İstanbul/year of XXXX', Persian-style numbers being used to indicate the year the conversion took place according to the Rumi or financial calendar (Figure 9). ${ }^{34}$ The 


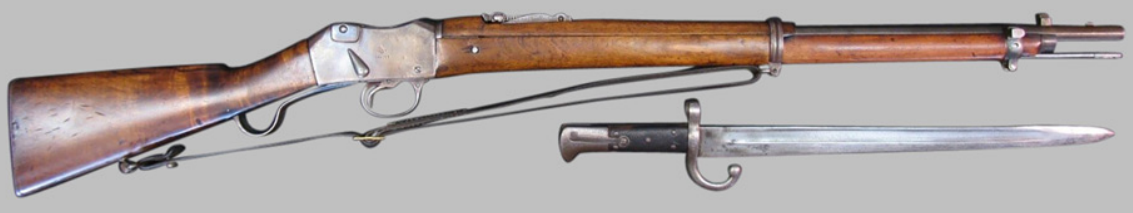

FIGURE 7. A post 1911/1912 converted Peabody-Martini Rifle, fitted for the $7.65 \times 53 R$ cartridge, with the shortened yataghan bayonet associated with this model, and the lug in front of the foresight for fitting a socket-bayonet in place of the yataghan-style bayonet (photograph supplied by John P. Sheehan).

known dates indicate the process lasted from at least I9I2/19I3 to I9I $5 / 1916,35$ with a fresh serial number being applied to the back of the breech mechanism (Figure Io).

Photographs reveal that these conversions were supplied to the notorious Fedais units during the Balkan Wars, ${ }^{36}$ and so they may well have seen service in that campaign with some reserve or even regular units at that time. They were certainly used at Gallipoli in I9I 5 by the Turkish 64th Infantry Regiment, ${ }^{37}$ and by an unknown regular unit at the Battle of Katia/Qatia on 23 April I916. ${ }^{38}$ Indeed, British Military Intelligence reports for that period note how 'Martini' rifles were employed-if mainly as a reserve weapon-throughout the Syrio-Palestine-Mesopotamian theatre, and that 'about I50 Martini's' were allegedly being converted daily at Constantinople to fire Mauser ammunition. ${ }^{39}$ However, I9I6 is the latest secure date for any form of 'Martini' type rifle being in regular service with the Ottoman army, the weapon probably being retired progressively from active duty once the Ottoman Empire began to receive supplies from Germany of surplus Gewehr 88/05 and Gewehr $98 .^{\circ}$ Certainly, there is as yet no evidence to suggest it was in use by any of the units involved in the Turkish War of Independence of 1919-1923, or by the later army of the Turkish Republic, which used these German-supplied Mauser rifles almost exclusively, all fitted with the appropriate German-supplied bayonets of original length. $^{4 \mathrm{I}}$

From an overview of the Peabody-Martini Rifle in Ottoman service we now turn to the bayonets with which it was fitted during its service life.

\section{The first Peabody-Martini bayonet-the socket-type}

As remarked above, the Ottoman government's initial choice of bayonet for the Peabody-Martini Rifle was a socket bayonet with a quadrangular sectioned 'blade', contemporary photographs revealing this fitted directly beneath rather than as usual along the right-hand side of the barrel (e.g. Figures I I and I2). It is in fact the 'blade' form and fitting system that, along with the socket bore diameter, allow the 


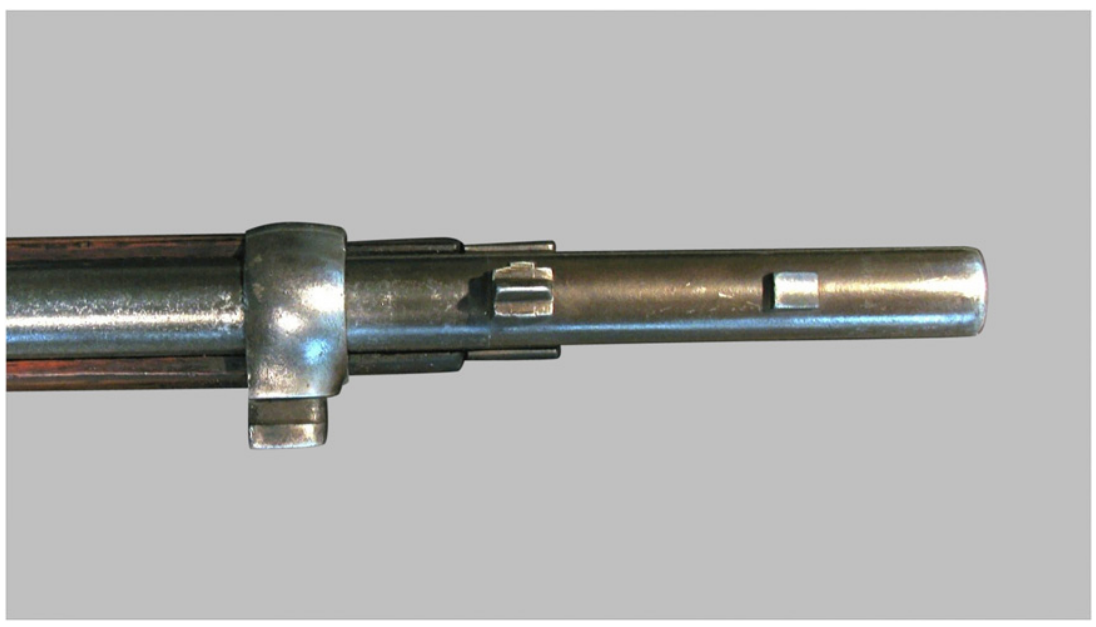

FIGURE 8. Detail showing the bayonet bar, foresight, and socket bayonet lug on a post-1911/ 1912 converted Peabody-Martini Rifle (photograph supplied by John P. Sheehan).

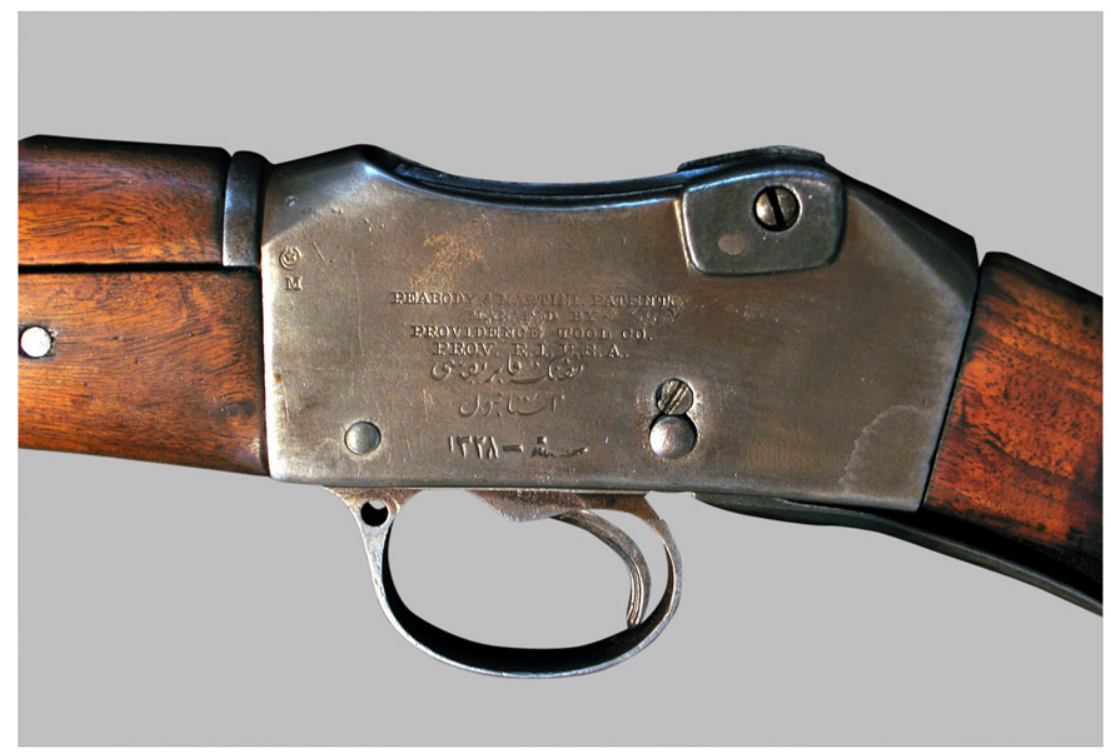

FIGURE 9. Left-hand side of a post-1911/1912 converted Peabody-Martini Rifle, dated to $1327=1912 / 1913$, with the strengthening plates added at the back of the chamber (photograph supplied by John P. Sheehan).

identification of a small number of all-steel socket bayonets as made for the Peabody-Martini Rifle as except for a rare few with single letter 'inspection marks', none of the identified examples have any other form of marking, either a maker's mark, or a serial number, or even as might be expected some indication of Ottoman ownership. ${ }^{42}$ 


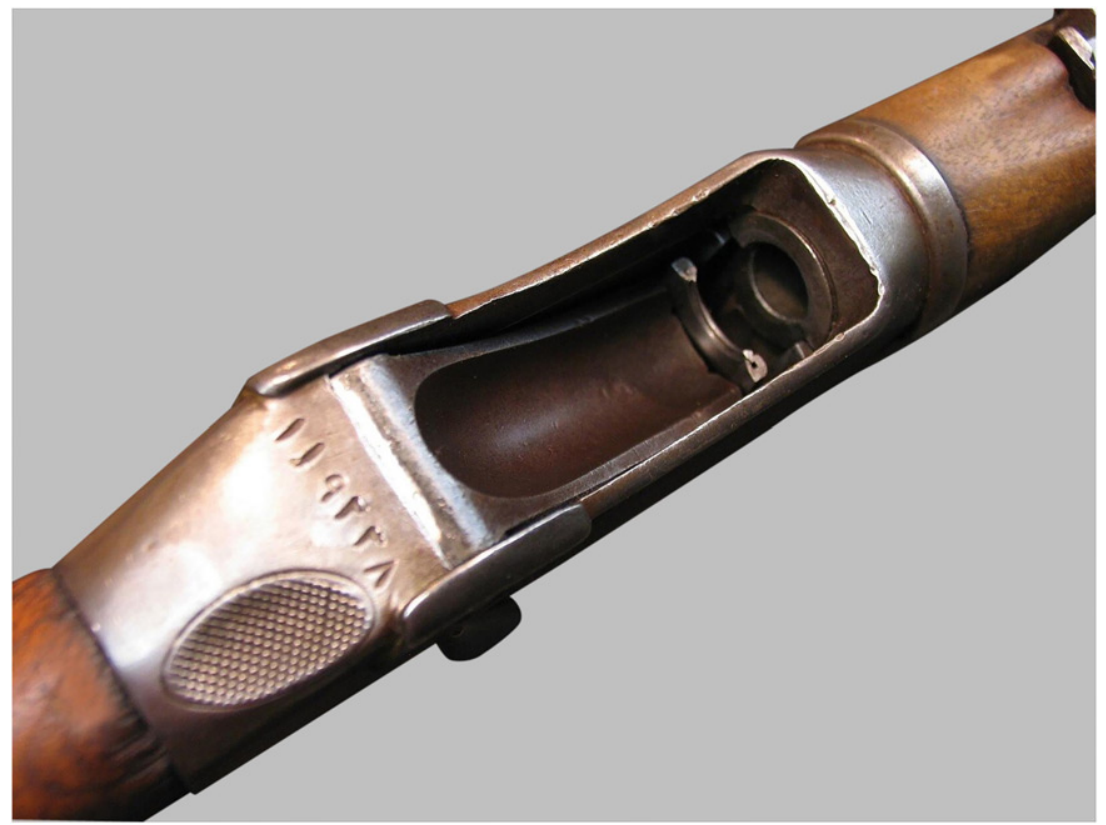

FIGURE 10. Detail of the breech assembly of a post-1911/1912 converted Peabody-Martini Rifle, with the serial number 119237, and showing the chequered thumb rest copied directly from the original pattern model for the Peabody-Martini Rifle (photograph supplied by John P. Sheehan).

We will return to these matters and others below, but first a short description of the Peabody-Martini socket bayonet and its scabbard, which in most other respects matches those of most other contemporary weapons of this type (e.g. Figure I3). That is to say, it has an overall length of 23.25 inches $(59 . \mathrm{I} \mathrm{cm})$, and was attached to the rifle via a 3.15 inch $(8 \mathrm{~cm})$ long socket, with a 0.79 inch $(2 \mathrm{~cm})$ external diameter and 0.69 inch $(1.75-1.82 \mathrm{~cm})$ bore, and a Z-shaped fitting slot, a tension band with a single tightening screw helping to secure the bayonet in place on the barrel. The quadrangular-sectioned 'blade' is 20.125 inches $(5 \mathrm{I} .4 \mathrm{~mm})$ long, with a 0.7 inch $(\mathrm{I} .8 \mathrm{~cm})$ diameter near the elbow, gradually tapering to 0.35 inch $(0.9 \mathrm{~cm})$ diameter just before the quadrilateral point, and weighs I 4 oz. (398 gr). When not fixed to the rifle the bayonet was housed in a black leather square-sectioned scabbard with a brass locket fitted with a tear-shaped frog stud and a square-ended brass chape.

The choice of a socket bayonet for the 600,000 Peabody-Martini Rifles commissioned originally by the Ottoman government was perhaps dictated for reasons of economy, for as we have seen above, the rifle with this form of bayonet was costed at \$I6.25 each as opposed to \$I7.50 with a sword-type bayonet. That said, although at the time socket bayonets were still found in use amongst some European and other armies, the introduction in I 866 of the French 'Chassepot' rifle with its yataghanstyle bayonet had encouraged a trend throughout most of Europe for the issue to line 


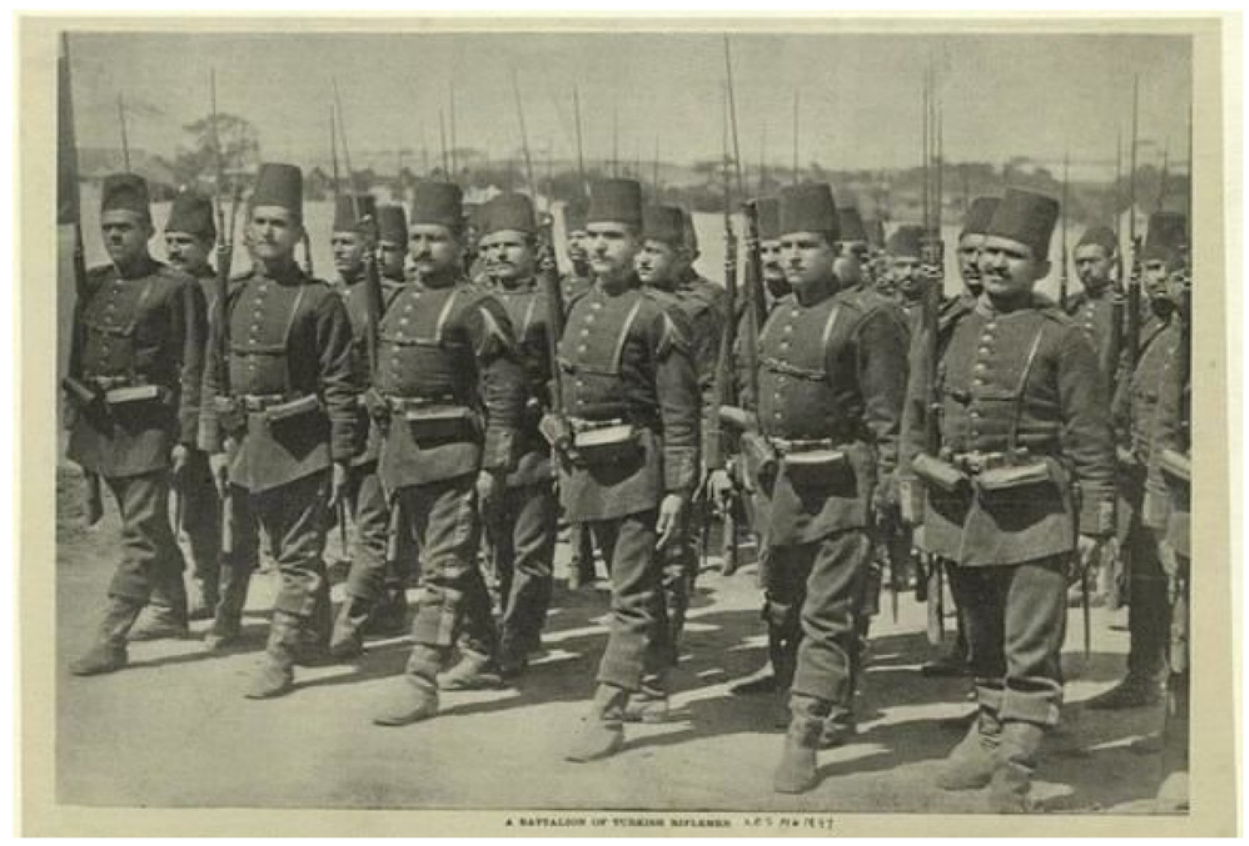

FIGURE 11. Newspaper photograph of about 1880 of an Ottoman Infantry unit with socket bayonets fitted to their Peabody-Martin Rifles (Photograph supplied by Bahadir Saydag).

infantry of this style bayonet and others of sword-type, such forms having previously been restricted generally to artillery and engineer units for clearing brushwood and the making of fascines, etc. But what is unusual about the Peabody-Martini socket bayonet is the choice of a quadrangular-section 'blade' instead of the flattened triangular form commonly used for socket bayonets since about the beginning of the eighteenth century. The choice of this form was probably directed by the Providence Tool Company which had supplied a bayonet of this type with the Peabody Model I 866 Rifles sold to the Swiss Army in I866 and I $867 .{ }^{43}$ However, socket bayonets with a quadrangular-section were highly unusual at this or any other time. Indeed, after its introduction with the Austrian Lorenz rifle of I854, the form was adopted by few other European armies, namely by the Swiss (with the Model 1863 Infanteriegewehr, the Peabody Model I866 Rifle, and the Vetterli Model I87I Repetierstutzeri); by Sweden (the Remington Rolling Block Model I867); by the Netherlands (the Beaumont Model I87I); and by Russia (the Berdan Model II I 87I).

What is quite uncertain is the reason behind the choice by any of these armies of a bayonet of this form. At first sight it might appear it was intended to inflict a wound that if not fatal was more complicated to repair, and indeed one contemporary account of the $1877-1878$ Russo-Turkish War notes-presumably from personal observation - of how the Peabody-Martini bayonet was 'capable of producing a particularly nasty wound'. ${ }^{44}$ Medical texts of the day offer no evidence on the matter, 


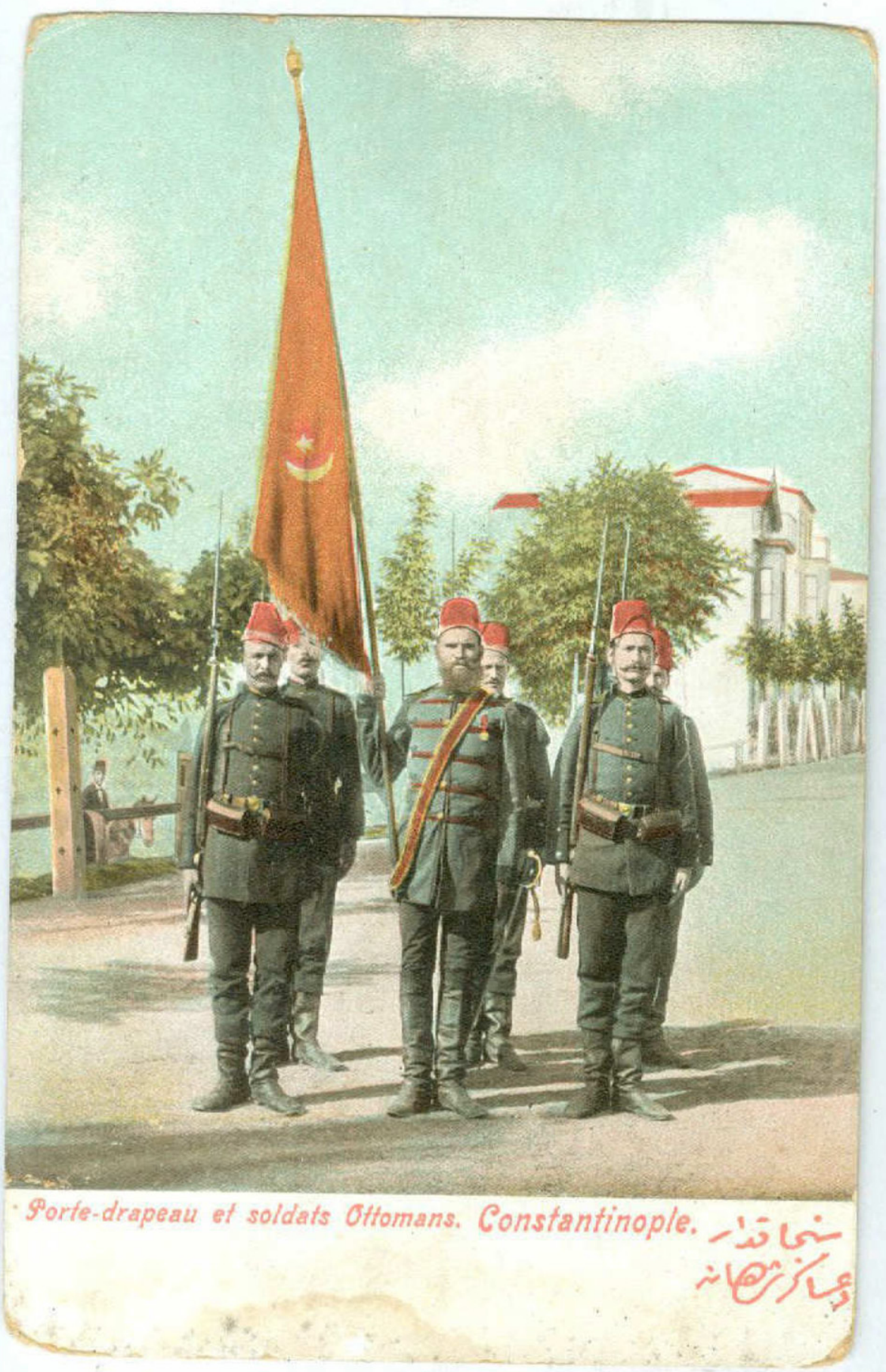

FIGURE 12. Postcard of about 1890 showing the Colour Guard for an infantry battalion, with soldiers carrying the Peabody-Martini and fixed socket bayonet (author's collection). 


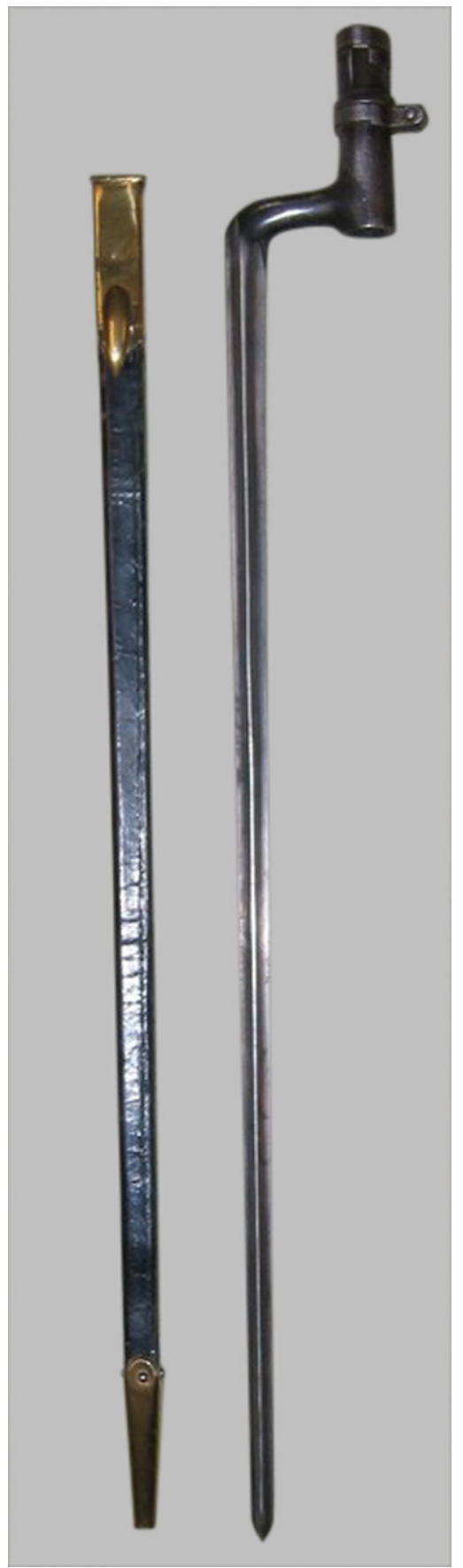

FIGURE 13. A Peabody-Martini socket bayonet and scabbard (photograph supplied by Mike Hibberd). 


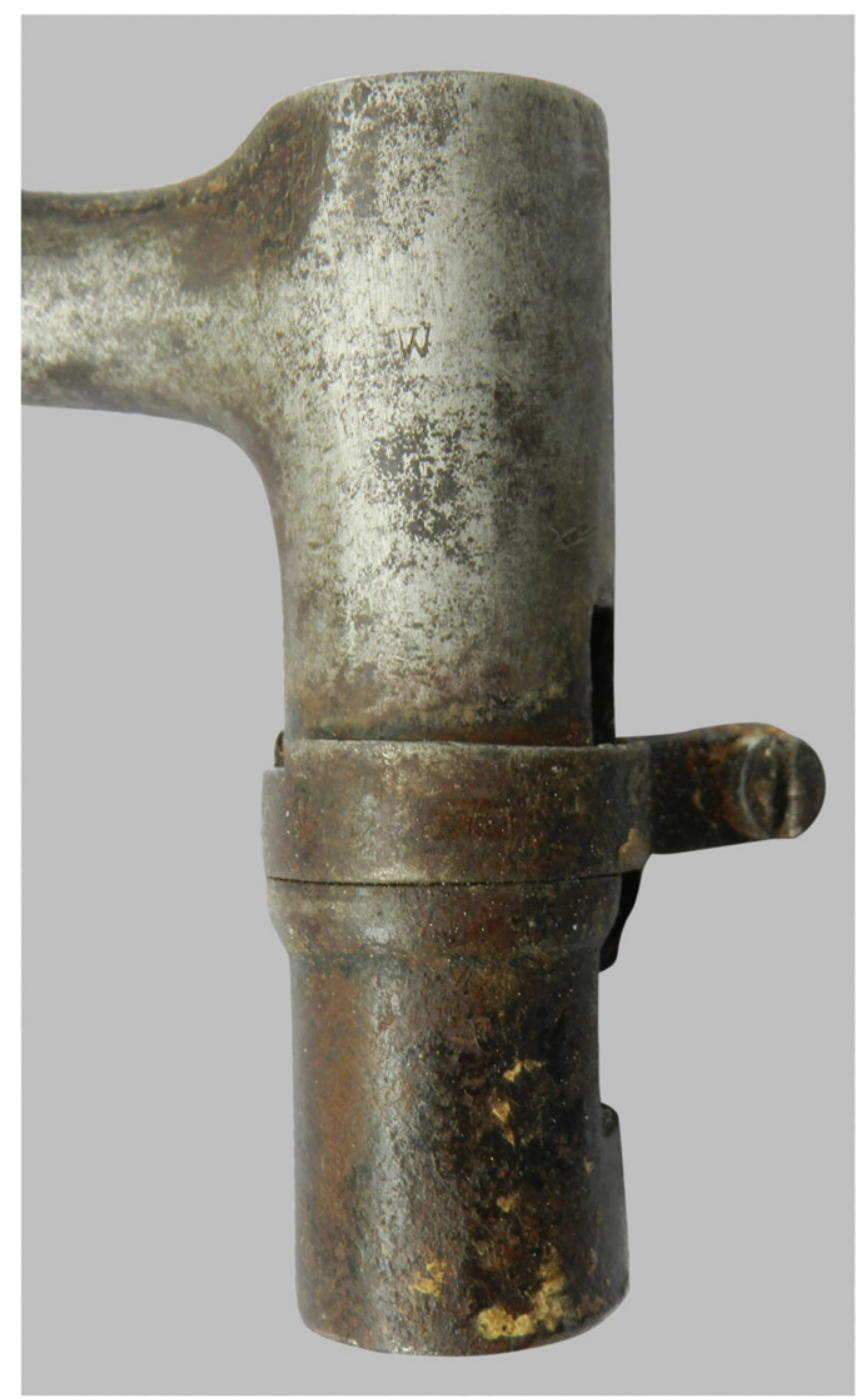

FIGURE 14. Inspection letters ' $W$ ' and ' $C$ ' on a Peabody-Martini socket bayonet (author's photograph).

though, and in fact even disagree as to the difficulty or otherwise of repairing the more usual triangular-sectioned bayonet wound. ${ }^{45}$ On the other hand, it might simply be that this 'blade' form, with the flutes serving akin to the ' $\mathrm{I}$ ' form of a steel girder, resulted in a stronger weapon than a bayonet of the same weight and more usual flattened triangular style found normally with socket bayonets, reducing the risk of the blade breaking if used too vigorously. Hence also, we might assume, the all-steel construction for the Peabody-Martini socket bayonet as opposed to the common method of brazing a steel blade to an iron socket, so eliminating the danger that the blade might snap off at the junction, although the Remington export quadrangular- 
sectioned bayonets do, somewhat surprisingly, have a steel blade fixed to an iron socket. Be that as it may, what also deserves comment is how instead of being mounted along the right-hand of the barrel, as was usual for socket bayonets, the Peabody-Martini socket bayonet was suspended directly beneath this, as were those fitted to the Dutch Beaumont and the Swedish Remington Rolling Block rifles. What made this possible in these cases was the use of a shorter cleaning rod that barely projected beyond its housing, another feature that incidentally distinguishes the Peabody-Martini from the Martini-Henry Rifle. Even so, the reason for this choice of under-the-barrel fitting is not entirely clear. Perhaps it was meant to give the rifle holder with fitted bayonet a direct line of sight when firing his weapon and when using the bayonet and rifle in pike-like fashion against charging cavalry or for potential bayonet fencing with enemy infantry.

As stated above, none of the known surviving examples of socket bayonets identifiable from their socket diameter, form, and method of fitting as being made for the Peabody-Martini Rifle bear any form of maker's mark, although some have the individual 'inspection' marks commonly found on bayonets of all types. Those instances known to the writer are one example with a single letter ' $\mathrm{W}$ ' and a ' $\mathrm{C}$ ' beneath it on the left-hand side of the socket (Figure I4); one with an ' $\mathrm{X}$ ' mark on the socket's right-hand side; and an example with a single ' $\mathrm{C}$ ' inspection mark on the left-hand side of the socket in the Royal Armouries collections. ${ }^{46}$ Even so, as the Providence Tool Company was, as its name indicates, primarily a tool-making concern, it is accepted generally that these bayonets were made 'in-house', as with those bayonets the Company supplied with their Peabody Model I 866 rifles. ${ }^{47}$ Certainly, it is surely no coincidence that the known inspection marks ' $\mathrm{W}$ ' and ' $\mathrm{C}$ ' on known PeabodyMartini bayonets do match in style and size examples of the same letters found on Peabody-Martini Rifles. But what is even more puzzling than the lack of a manufacturer's mark is the complete lack of any serial numbers on the known examples or any form of Ottoman ownership mark for that matter, which, if nothing else, helps distinguish clearly the Peabody-Martini socket bayonets from the almost identical quadrilateral-sectioned beneath-the barrel bayonets made for the Dutch Beaumont and Swedish Rolling Block rifles. Aside from their different socket and 'blade' dimensions, these Dutch and Swedish analogues commonly have maker's marks, serial numbers and/or some other identifying designation on one or other side of the socket and/or its elbow.

Shape, all-steel construction, and the under-the-barrel fitting of the PeabodyMartini socket bayonet aside, its length and weight warrants further comment. When fitted to the rifle the Turkish soldier carried a weapon with a weight of 9 pounds 6 ounces $(4.28 \mathrm{~kg})$, and a length of around 5 feet 9 inches $(175 \mathrm{~cm})$. To modern eyes this overall length and weight might seem excessive at first, but in fact it compares well with the length and weight of the Martini-Henry Rifle with a fixed bushed Pattern I 853 bayonet, at around 5 feet 6 inches $(\mathrm{I} 67 \mathrm{~cm})$ and 9 pounds 7 ounces $(4.29 \mathrm{~kg})$ overall. The reason behind the overall length of both rifles with a 


\section{PLATE No. 4. \\ PeABody-Martini Military Rifle}

WITH QUADRANGULAR AND SABRE BAYONETS.

3,300,000 SHOTS FIRED,

From 550,000 of these Rifles, by United States Government Inspectors, at the Providence Tool Company's Works, WITHOUT ACCIDENT.
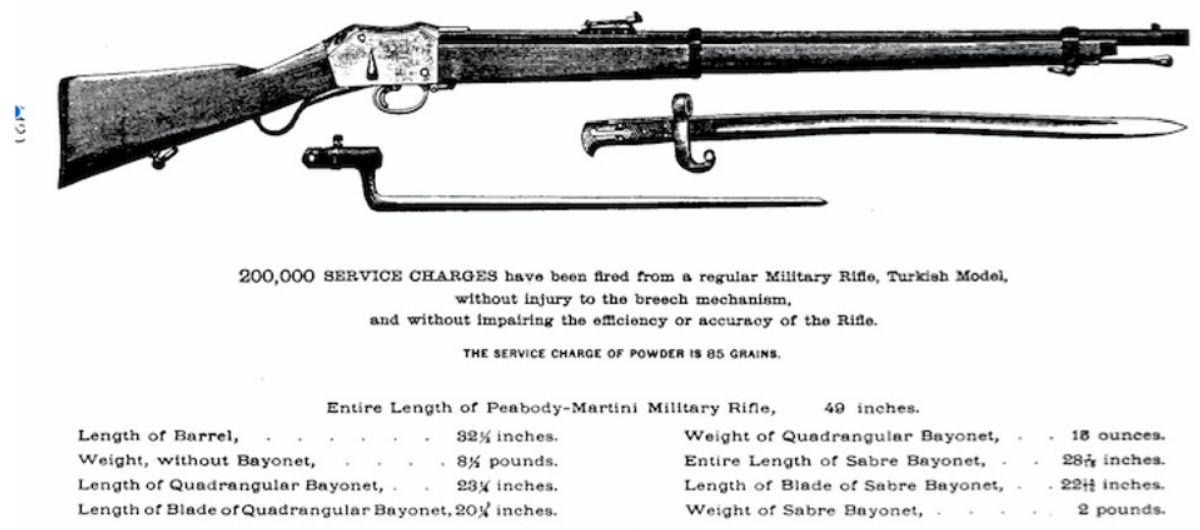

CALIBRE, 100 INCH.

FIGURE 15. Illustration of the Peabody-Martini Rifle and bayonet, taken from the 1878 Providence Tool Company Catalogue (author's photograph).

fixed bayonet is related to their use in an age where eighteenth century field tactics remained in vogue. That is to say, using blanketing artillery-fire focussed on the planned point of attack, followed at the appropriate moment by an elbow-to-elbow charge with the bayonet as the decisive strike, even if more usually than not with the bayonet providing a psychological weapon to scare off the opposition rather than for bayonet fencing and close combat per se. ${ }^{48}$ Hence the way that the gradual change from smooth-bored muskets to the more accurate rifles had seen the barrel-length progressively reduced and so the need in the mid-nineteenth century for longer bayonets to provide the 'bayonet reach' suitable for transfixing a charging mounted cavalryman if necessary and the possibility of close combat with an enemy through bayonet fencing. ${ }^{49}$

\section{The second Peabody-Martini bayonet-the yataghan type}

As we have seen, in January I875 it was agreed to supply the last 200,000 PeabodyMartini Rifles of the 600,000 commissioned by the Ottoman government with a sword bayonet, requiring the fitting of a top barrel band with a bayonet bar projecting on the right-hand side of the rifle (e.g. Figures 5 and 6). ${ }^{\circ}$ The contemporary 
Providence Tool Company literature and photographic evidence indicate this sword bayonet was of the then fashionable yataghan form (e.g. Figure 15 ), ${ }^{5 \mathrm{I}}$ and at least some of these 200,000 rifles and their yataghan bayonets had arrived in Constantinople by May I 877 in time for use during the I 877-1 878 Russo-Turkish War. ${ }^{52}$ As with the Peabody-Martini socket bayonets, though, none of the many surviving original examples of this bayonet have any form of maker's mark, a matter we will return to below, although 'inspection' marks are common, nor do they have any form of ownership mark or serial number. Even so, just as with the Peabody-Martini socket bayonets, the contemporary illustrations aside, muzzle-ring diameter and that lack of any maker's or ownership mark makes the identification of surviving examples of this bayonet a straightforward matter, as does their ubiquity in Turkish museum and private collections and auction sites.

The bayonet itself (Figure 5) has an overall length of 28 inches $(7 \mathrm{I} 4 \mathrm{~cm})$, with a one-piece all-steel blade and tang, the steel pommel and crossguard being brazed into place. The pommel has a T-shaped mortise slot, while the crossguard has an upright upper quillon pierced by a 0.67 inch $(1.7 \mathrm{~cm})$ diameter muzzle ring, the forwardcurved lower quillon terminating in a prominent circular finial with a flattened cross section. The hilt assembly is completed by black pressed leather grips impressed to imitate, it would seem, the more expensive snake-skin wrapped hilts found on officer's swords - such grips being commonly found on many European and other midnineteenth century sword bayonets - these being fixed to the tang by five steel rivets along with a leaf-spring and button release mechanism. As for the recurved and fullered blade, this was 22.6 inches $(575 \mathrm{~mm})$ long, resulting in a weapon that weighed some 2 pounds $(907 \mathrm{gr}$.). When not in use the bayonet was kept in a matching recurved leather scabbard, stitched at the rear and with two impressed lines running along the face, the steel locket having a scalloped lower edge and round frog stud, the steel chape, of rearward facing curved form, scalloped on the upper edge and terminating in a ball finial (Figure I6).

The lack of a maker's mark on these yataghan bayonets does not allow us to establish for sure who made them. The Providence Tool Company certainly had experience in making edged weapons having been commissioned to produce Io,4 I I Model I 860 sabres for the Union Army between January I 862 and July I 863, that is to say, at the peak point of the American Civil War. ${ }^{53}$ However, many of the production examples were rejected at the official inspection stage, although such was the need for sabres at this stage of the conflict that they were accepted eventually as meeting at least 'serviceable quality'. It is perhaps in the light of this fact that some believe these yataghan bayonets were produced by one of the reliable sword makers of the time, specifically the Ames Manufacturing Company, then based at Chicopee Falls, Massachusetts, ${ }^{54}$ the leading American sword-maker of the day. While it is true that the Ames concern had experience in making bayonets also, as with the USA Model I 847 and Model I 870 bayonets, these, along with the swords made by the same company, are invariably marked on the ricasso to indicate this, this mark in the 
I 870's taking the form of 'AMES MFG CO'/CHICOPEE/MASS. ${ }^{55}$ Thus we might justifiably doubt the view the Ames Company produced the Peabody-Martini bayonets, and suggest that they were in fact made by the Providence Tool Company itself.

There is, in fact, some evidence to support this proposal in the form of the 'inspection' letters on these yataghan bayonets. They are normally found as individual letters stamped usually on the right-hand ricasso only, but sometimes on the right-hand face of the crossguard, and more rarely on the upper surface of the tang, the pommel head, and the inner face of the locket and chape, and even on the odd occasion in triplets under the pommel. The recorded individual letters are 'B'. ' $\mathrm{C}$ ', ' $\mathrm{E}$ ', ' $\mathrm{H}$ ', 'S' and 'W', the last being the most common and generally restricted to the blade ricasso, often in combination with a ' $\mathrm{B}$ ' or an ' $\mathrm{H}$ ' on the crossguard (e.g. Figure I7); the two known cases of triplets are 'TKR', with the 'R' on its side, and 'AHS', with the ' $H$ ' likewise. Of the individual letters used on these yataghan bayonets, identical versions in form and size of the 'C', ' $\mathrm{H}$ ' and ' $\mathrm{W}$ ', have been identified on several Peabody-Martini Rifles, ${ }^{56}$ which - while not conclusive-strongly suggests these yataghan bayonets were indeed made by the Providence Tool Company. Certainly, although this point should not be over emphasised, it might not be entirely coincidental that their scabbards are marked with a cursive ' $\mathrm{B}$ ' just below the locket (Figure I 8), quite possibly for the contemporary Providence leather-goods maker R. A. Butler. ${ }^{57}$

Returning to the matter of the bayonet proper, in a sense the use of a yataghanshaped blade adopted for the post-I 875/77 Peabody-Martini Rifle might be seen as a case of 'taking coals to Newcastle'. After all, this particular recurved blade shape, sloping down from the crossguard and then up towards the point, and fluted on both sides for a better rigidity and weight factor, was inspired ultimately by the Turkic-origin sword of the same name, a cutting weapon intended originally for cavalry use. The precise origin of the weapon form is unknown. One Ottoman tradition ascribes it to 'Yatağan Baba', a thirteenth century swordsmith living in what is now Yatağan in modern Turkey's Denizli province, the fame of the weapon he produced giving its name to the place where it was first made, although another tale is that it took its name from the practice of wearing the sword thrust through a belt or sash in a near horizontal position, as the Turkish word 'yatağan' can be translated as 'lying down'. ${ }^{8}$

What is certain is that after its initial introduction in bayonet form into Europe with the French Model I 840 musket, this style of blade, combining great strength and a degree of flexibility, whether used as either a bayonet or a sword, became increasingly common as the fashion for sword bayonets developed in mid- and laternineteenth century. A major factor in its initial popularity, though, was perhaps not so much fashion but practicality, it being safer - and easier - to reload a muzzle-loading musket with a yataghan bayonet affixed, given how its point was aligned away from the muzzle mouth. That aside, the fashion for yataghan bayonets continued after the introduction of breech-loading rifles such as the Martini-Henry itself, 


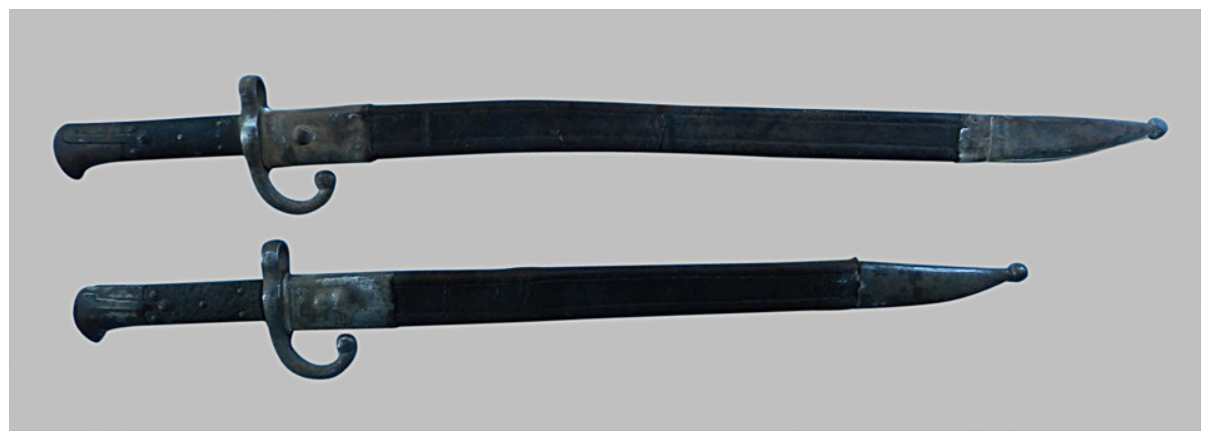

FIGURE 16. Examples of a full-length and shortened Peabody-Martini yataghan bayonets in their scabbards, the full length one showing a repaired shape (author's photograph).

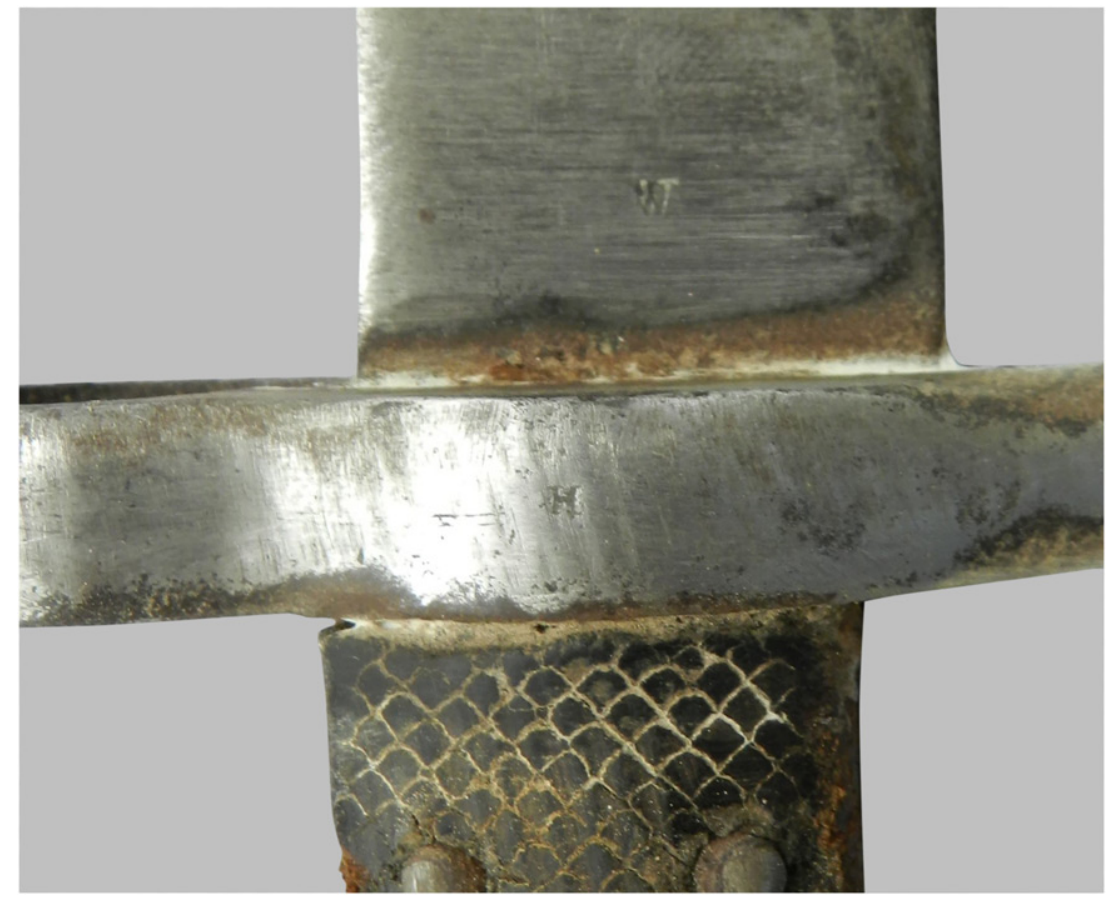

FIGURE 17. Inspection marks ' $W$ ' and ' $H$ ' on a Peabody-Martini yataghan bayonet (author's photograph).

cavalry and artillery units being issued with these on account of their need for a bayonet that could be used mainly as a side-arm, as a cutting weapon if needs be, but which could in extremis might also be used as a thrusting weapon when affixed to a rifle. ${ }^{59}$ We have, unfortunately, no clear evidence regarding which units of the Ottoman army were issued with the Peabody-Martini yataghan bayonets except that they were certainly supplied to the light infantry Tallia or Chasseur battalion attached to each Ottoman regiment. ${ }^{60}$ Be that as it may, whatever the reason for 


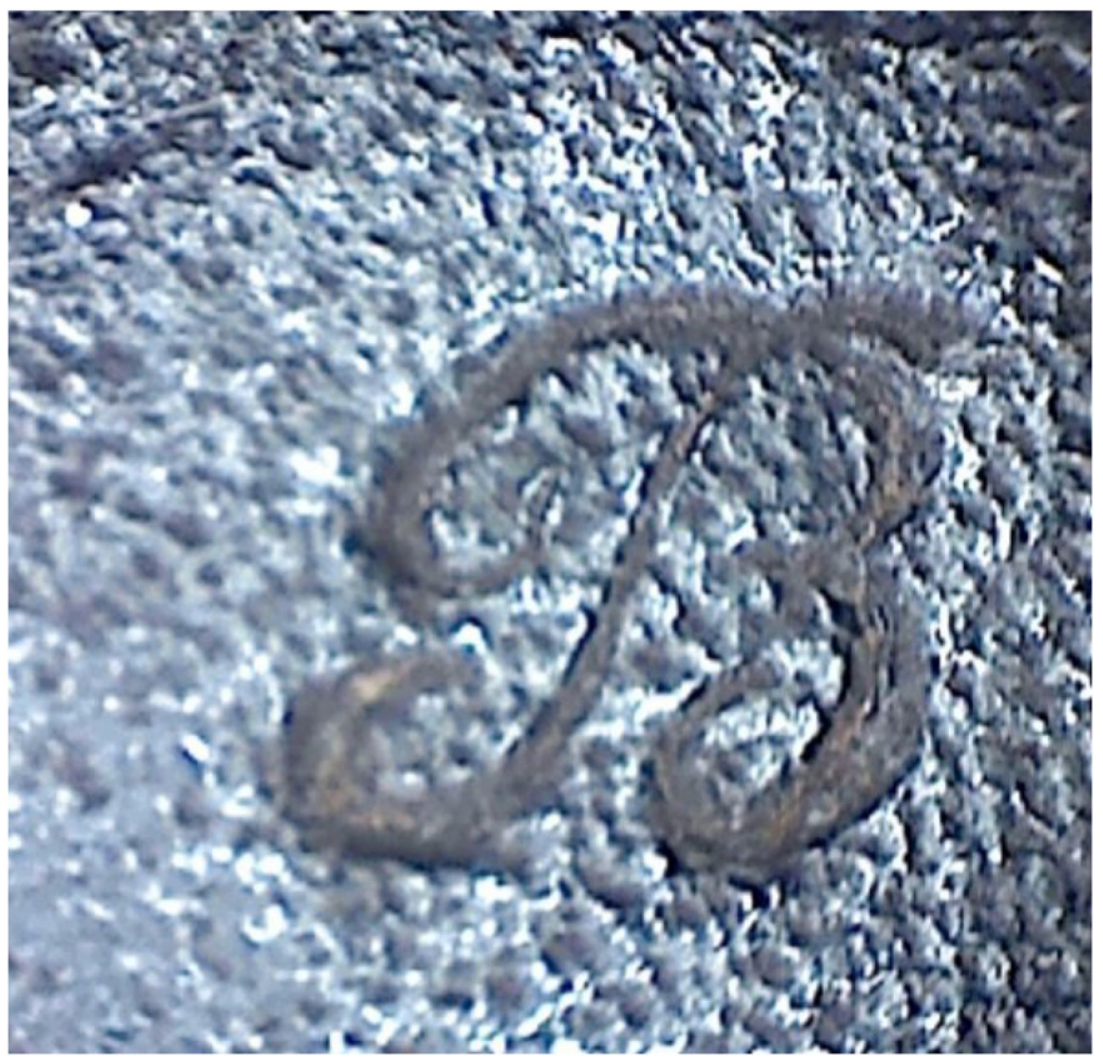

FIGURE 18. Detail of scabbard marking beneath the locket on the top scabbard in Figure 15 (author's photograph).

adopting this style of bayonet, when fixed to the rifle, its' all-steel construction, and length and weight made for a significantly heavier and longer weapon all round, the Peabody-Martini Rifle with fixed yataghan bayonet having a weight of about Io pounds 8 ounces $(4.87 \mathrm{~kg})$ and a total 'reach' of about 6 feet $(\mathrm{I} 8 \mathrm{I} .6 \mathrm{~cm})$. How this may have affected individual marksmanship skills at close range must remain a matter of speculation, although as was demonstrated at the Siege of Plevna, high trajectory plunging volley fire was a favoured Ottoman infantry tactic, and proved exceedingly effective at a range of up to 2000 or so metres.

\section{The Third Peabody-Martini bayonet-the shortened and straightened yataghan type}

Many Turkish museums and private collections have examples of Peabody-Martini yataghan bayonets shortened and straightened to give a blade length of around I 8 inches $(46 \mathrm{~cm})$, reducing its overall weight to around I pound I 2 ounces ( $800 \mathrm{gr})$. 


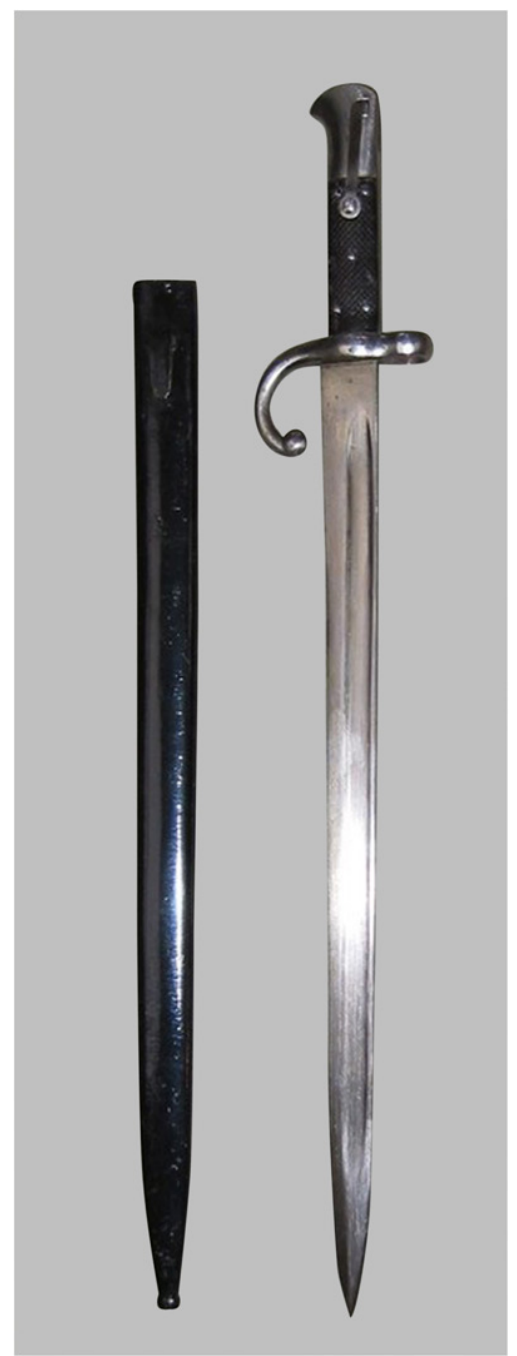

FIGURE 19. Shortened Peabody-Martini with steel scabbard (photograph supplied by Mick Hibberd).

These bayonets were usually housed in a shortened version of the original scabbard (e.g. Figures 6 and I 5), although one reported example has a squared-off chape in the manner of a Mauser Model I 887 scabbard, and purpose-made steel examples with straight sides are known (e.g. Figure I9). The procedure involved in producing these weapons was evidently to cut through and dispense with the last 4 inches $(10.5 \mathrm{~cm})$ of the original blade at a point just beyond where the fullers ended, followed by hammering flat and shaping a new point, then grinding out the bottom edge of the blade. The result was to give the weapon a straightened appearance, although a ruler placed along the blade spine reveals that few are anywhere near exactly straight. ${ }^{6 \text { I }}$ 


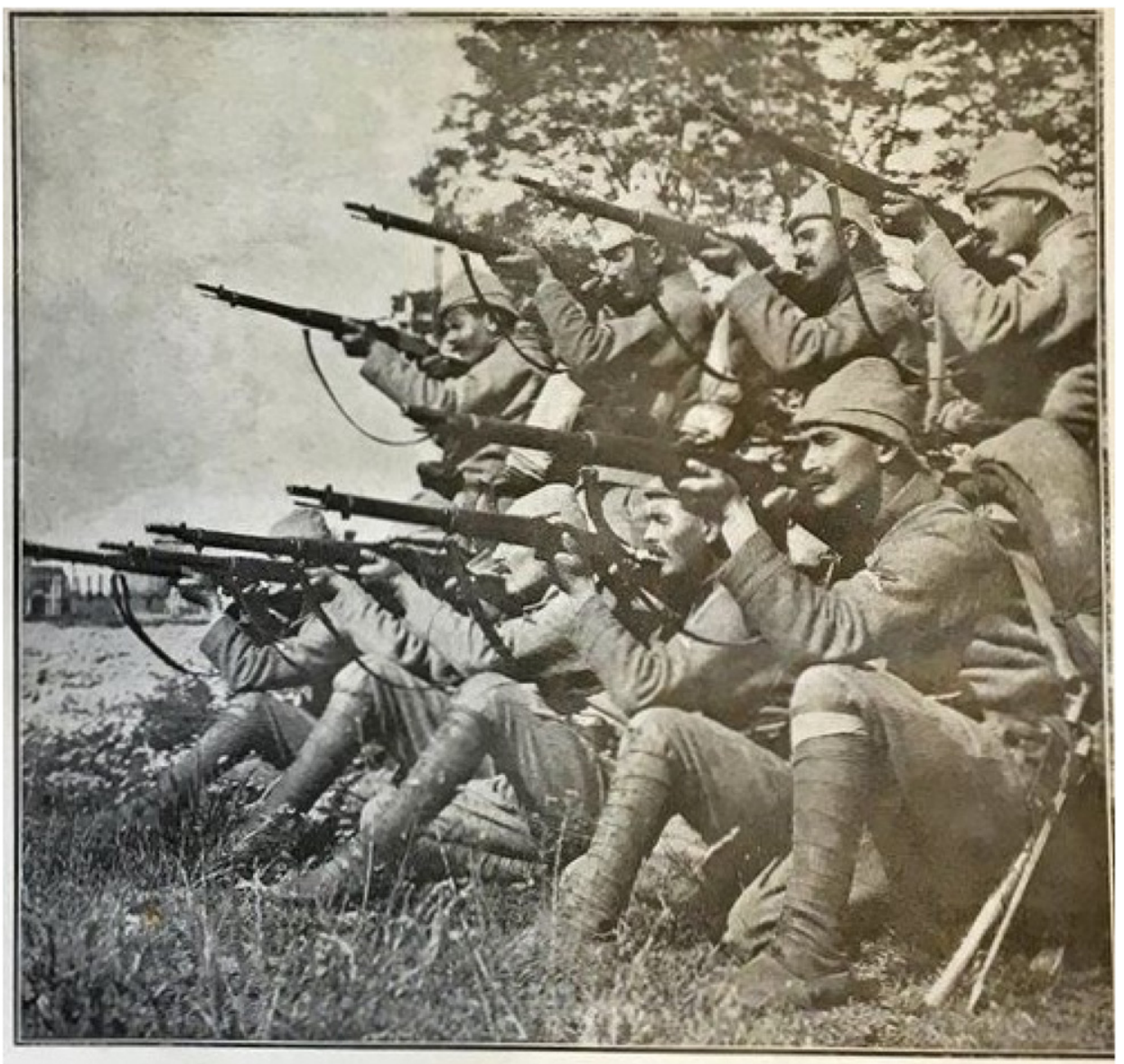

FIGURE 20. Illustration from the front cover of the Ottoman magazine 'Harp Mecmuasi' dated Mayıs 1332 (May 1916) (author's photograph).

As we have seen, when it was decided to convert at least 173,778 of the 'obsolete' Peabody-Martini Rifles to fire the Mauser $7.65 \times 53$ cartridge the Ottoman powers that be-fully wedded to the principle of 'waste not want not'-insisted the new barrels be tailored to fit the original Peabody-Martini bayonets to allow their continued

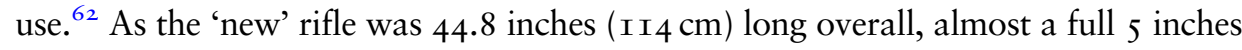
$(\mathrm{I} 2.7 \mathrm{~cm})$ less than the original, it seems logical to associate these shortened yataghan bayonets with the introduction of the shorter rifle, so giving an Ottoman infantryman a weapon that, with bayonet fixed, weighed about I I pounds $(5 \mathrm{~kg})$, and measured some 5 feet $\mathrm{I}$ inch $(\mathrm{I} 66 \mathrm{~cm})$ overall butt to blade point.

Linking these shortened bayonets with the shortened rifles might seem an entirely reasonable assumption, as firing a shortened rifle fitted with an original length yataghan bayonet would affect its balance and accuracy, as well as producing a rather unwieldy and unmanageable weapon for close combat. ${ }^{63}$ There is, however, no 


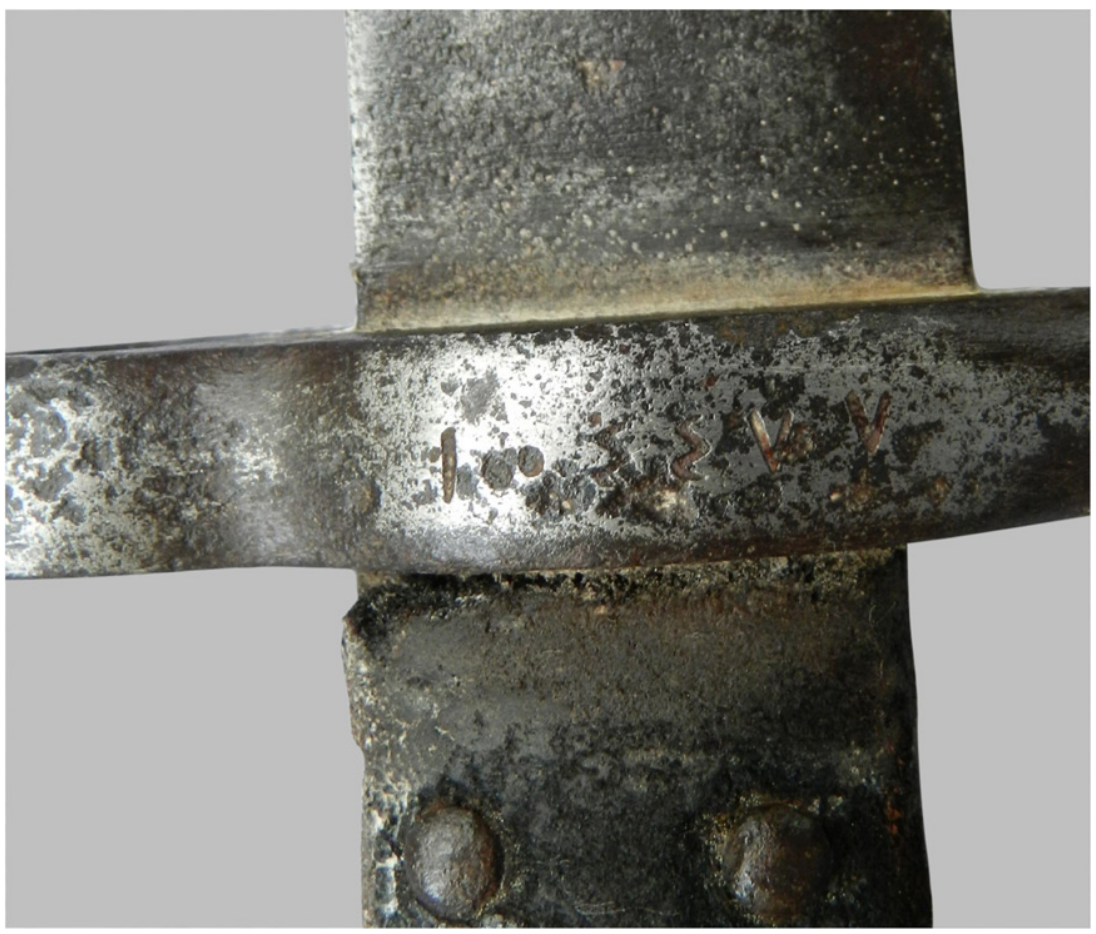

FIGURE 21. Serial number 104477 on a shortened Peabody-Martini bayonet (author's photograph)

explicit evidence to support the idea. For example, it is clear that some troops supplied with the converted rifle used socket bayonets (Figure 20). ${ }^{64}$

Moreover, there is some evidence to indicate how shortened yataghans were provided as a sidearm by those men ranked as Bascavus, or sergeant-major, ${ }^{65}$ which might explain why some of these have their catch mechanisms removed and original leather grips replaced with wooden ones. On the other hand, all the known examples of these modified yataghan bayonets that have not had their crossguards altered subsequently in any way have a serial number on their right-hand side, the lowest recorded example being 23,383 and the highest 104,477 (e.g. Figure 21).

Evidently, unlike the socket or normal-length yataghan bayonets, these were registered in some way, perhaps on issue to individual soldiers, and possibly numbered to correspond with the serial numbers on the breech blocks of the converted rifles. This cannot be proven. However, we might note here that all those bayonets supplied with the various types of Mauser rifles that began to be issued to the Ottoman army in I $887 /$ I 888 were likewise serial-marked on their crossguard. Thus, we can reasonably assume that the decision to serial-mark these shortened Peabody-Martini bayonets followed on from the pattern set by the systematic serial-marking practice employed for the shortened rifles and with these German-made bayonets. 


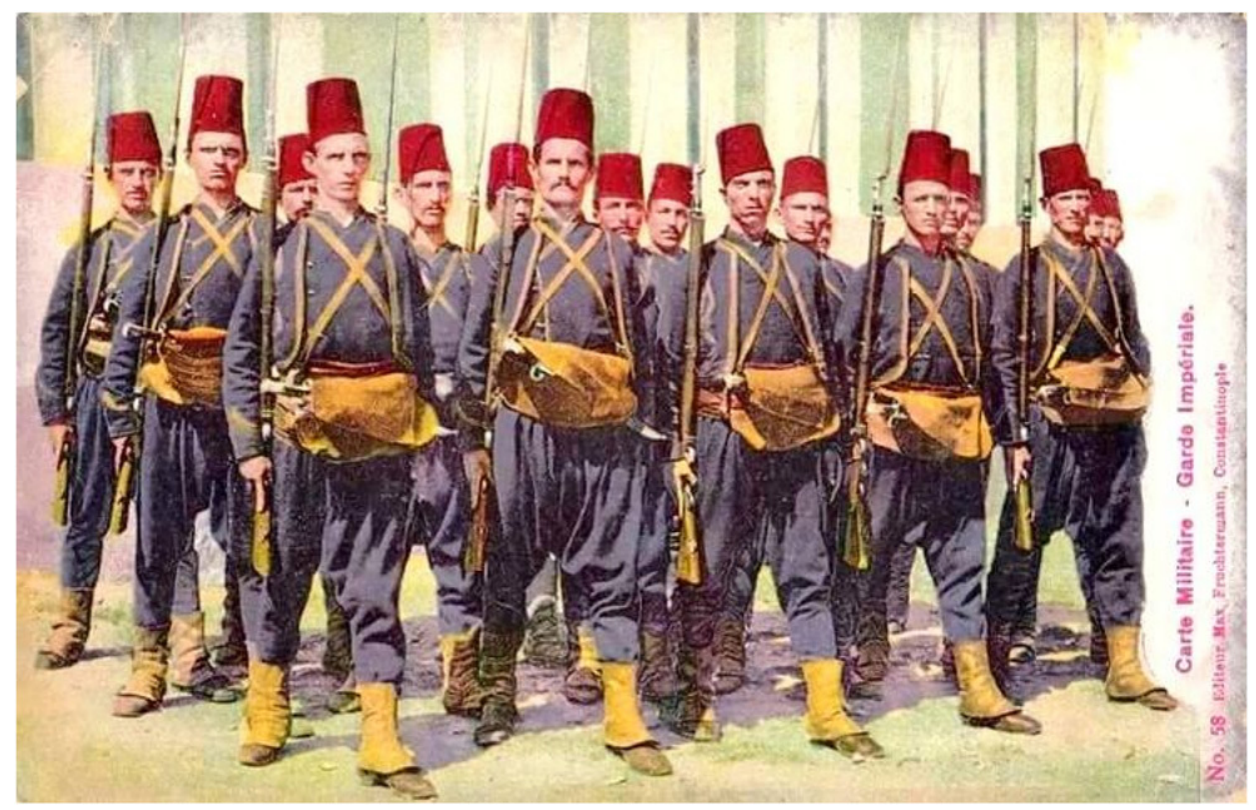

FIGURE 22. Post card of the Albanian battalion of the Imperial Guard, with socket bayonets fitted to their Peabody-Martini Rifles, and yataghan bayonets in their bensilanar (author's collection).

\section{Envoi: A Bayonet for all seasons}

By way of concluding this article we might simply remark on how the three forms of bayonet fitted to the Peabody-Martini Rifle from its introduction into Ottoman service in I874 to its eventual replacement as a standard service weapon by Germansupplied Mausers in I9I6-I9I7 provide an excellent paradigm for the changes in bayonet styles during the last decades of the nineteenth century and the initial two of the twentieth. Thus the first socket-type bayonet of I 874 conforms to the standard needs and tactics of late nineteenth century warfare (and, for that matter, as still practiced in World War One): namely the artillery barrage followed by the bayonet charge to at least demoralise the enemy if not necessarily engage in one-on-one bayonet fencing. It may well be that that the introduction of the second yataghan-style of I $875 /$ I 876 reflects an initial decision to satisfy the needs of mounted and/or artillery units for a cutting weapon fixable to a rifle. There is, however, no clear evidence on this matter, other than that they were used by units of Tallia, Turkish light infantry who filled the role of Chasseurs a pied, ${ }^{66}$ and so trained for rapid action and for whom a sword-type weapon would be of great use in close combat. However, these yataghan bayonets were certainly supplied to various Imperial Guard units, including the Ist Albanian Regiment, which was armed with socket bayonets for their rifles and yataghan bayonets carried Balkan-style in a bensilan, a leather bag slung in front of the belly containing a pistol and other necessary items (Figure 22). As such, 
therefore, we might see the issue of the yataghan bayonet as one dictated as much by prestige as by direct need, in which case they may well have served as a NCO's sidearm in other infantry units. As for the third style, the shortened yataghan, its introduction clearly corresponds to the introduction of shorter rifles using a smaller calibre cartridge, and thus the need for a bayonet of a length that would not affect the rifle's balance and be more manoeuvrable in close combat.

\section{Acknowledgements}

I greatly appreciate the supply of photographs and permission to publish these by Bahadir Saydağ, (collector); John P. Sheehan (independent researcher, USA), Mike Hibberd (former Conservator, the Imperial War Museum); and Nick Stanev (independent researcher, USA), and the John Ward collection (USA). I owe a great debt also to David Hughes, Society of American Bayonet Collectors and editor of their journal for forwarding information regarding PeabodyMartini bayonets, and the reference staff of various libraries, especially at Bilkent University for their help in securing reference material, namely Semra Kesler (Humanities), and Fusun Yurdakul (Inter-library Loans); also Evgeni R.Radushev (Department of History, Bilkent University) for his unstinting help with Osmanlıcı matters, and Eda Doğa Aras (Bilkent University), for help with my research. Finally, thanks are owed to the many collectors and others in Turkey, the United Kingdom and Europe, and the United States of America, for supplying information on Peabody-Martini bayonets in their own private collections, but it would be invidious not to mention especially Vernon Easley (Martini-Henry specialist, USA), Ed Hull (Independent Researcher, the Peabody Tool Company), Chis Flaherty (Ottoman Army specialist) and Andrej Blazicek (Indpendent Researcher, Slovakia). Also, Lisa Traynor, Firearms Curator at the Royal Armouries, Leeds, for her extraordinary patience in letting me 'rifle' through the collections she oversees for any Peabody-Martini related material there. Last but not least, I am of course indebted to the anonymous reviewer, and to Henry Yallop, Graeme Rimer, and John Ballard, for their contributions in improving the article overall; the final product, however, 'warts and all', is mine.

\section{Addendum}

It would be remiss not to comment properly on an aspect of the PeabodyMartini bayonet that the anonymous reviewer noticed in the original text and which was not discussed further there. Namely my 'throw-away' suggestion that some Peabody-Martini Rifles perhaps saw some form of service use after I9I6/I9I8. The evidence for this suggestion was simply the scant few known examples of all three types of Peabody-Martini bayonets-socket and sword-type-with their blades shortened to around 9.5/9.75 inches (24/ $25 \mathrm{~cm}$ ). 'Scant' is certainly the key word here for only one socket bayonet 
treated this way is known to exist (in the Graham Priest collection), and precious few sword-type Peabody-Martini bayonets shortened the same way have been reported. I initially likened these examples to the Io inch $(25.4 \mathrm{~cm})$ long knife bayonets in standard use by the army of the Turkish Republic from I935 to circa I959, suggesting-from their length-they belonged to that period. Further research prompted by the anonymous reviewer proves my suggestion quite unwarranted. To begin with, I had unforgivably overlooked how in I9I3 the 'Top Hane' or 'Cannon Yard' in Constantinople began producing bayonets of the 9.75 inch $(25 \mathrm{~cm})$ length for use with the 'Turkish' Model I890, I893 and I903 Rifles, photographs indicating these were in use certainly at Gallipoli in I9I5. Given their rarity on the auction and sales markets, these were evidently produced in very small numbers, as were those sword bayonets originally made for the same Ottoman rifles that were cutdown to a similar length-indeed, the cut-down version of the narrow-bladed bayonet produced for the Model I903 Rifle, modelled on the contemporary German pipe-backed S.98, is quite indistinguishable from the I9I3 knife-bayonet except at close sight. In addition, I had equally quite unforgivably overlooked how the same blade length is found on those just as rare Germanmade all-metal 'Ersatz' knife bayonets made for the 'Turkish' Model I 890, I893 and I903 Rifles, their crossguards having a recess to allow for the cleaning rod of the latter. These Turkish 'Ersatz' were presumably made at about the same time as the German 'Ersatz' bayonet family, that is to say, from late I9I4 until mid-I9I5. What is perhaps significant here, though, is how many of the original 'Top Hane' I9I3 bayonets and the shortened bayonets originally made for the Model I890, I 893 and I903 Rifles, still bear the Sultan's monogram, while this has been removed from many others of the same types that were stamped 'AS.FA' for 'Askeri Fabrika' the 'Military Factory' at Kirıkale, an entity set up in the late I930s when the Turkish Republic began to refurbish and systemise its stocks of weaponry. The conclusion I draw from this is that the shortened bayonets for the Model I 890 , I 893 and I903 Rifles belong to the period before the Sultanate was abolished in I922, and were shortened to match the length of the I9I3 'Top Hane' and Turkish 'Ersatz' bayonet, both of which saw service in World War One. In which case, it is entirely conceivable that those Peabody-Martini bayonets shortened to the same length represent ad-hoc unofficial conversions made by unit armourers to match the new and 'fashionable' 9.75 inch $(25 \mathrm{~cm})$ length.

\section{Notes}

${ }^{\text {I }}$ Such is the name by which this rifle it is usually known today and as given in contemporary advertisements in the USA, e.g. as in a Providence Tool Company sales catalogue for I 878, reproduced here as Figure I4, and so the practice is followed here. As far as the Ottoman government was concerned it was a MartiniHenry: e.g. The New York Herald, I3 August I877, p. 3, col. 2, on-line at http:// chroniclingamerica.loc.gov/lccn/sn830303 I3/ I 877-08-I3/ed-I/seq-3/ [accessed I 5 December 20I8] with other instances noted below.

${ }^{2}$ Martini had obtained and improved a sample of the Peabody mechanism in about I 867 after 
the Swiss army adopted the Peabody Military Rifle of I 866: see, e.g. E. A. Hull, Providence Tool Co. Military Arms, 2nd edn (Milton FL, I979), p. I2; W. O. Achtermeier, Rhode Island Arms makers and Gunsmiths I643-I883 (Providence RI, I980), pp. 33-44. It was this combination that, with the addition of the rifle barrel patented in 1860 by A. Henry, became the basis of the British Martini-Henry 'First Pattern' Rifle in I87I and its subsequent versions. The Peabody-Martini also used a Henry-rifled barrel (which is why some collectors prefer to refer to the weapon as the Peabody-Martini-Henry), and it was sometimes advertised as identical to the English Martini Henry except in the cartridge chamber and extractor', e.g. the Army and Navy Journal i 9 (I), issued 6 August I86I.

${ }^{3}$ For a detailed but not exhaustive account of the development of the Peabody-Martini Rifle itself, including Henry's failure to have his patent rights acknowledged for the use of his rifling system in this, see now J. Bennett, 'The "Aynali Martini": the Ottoman Army's first Modern Rifle', Anatolica 44 (2018), 229-255; and for earlier summary accounts of the rifle's development, Hull, Providence Tool Co., pp. 20-22, and Achtermeier, Rhode Island, pp. $37-44$.

${ }^{4}$ J. C. McCoan, Egypt under Ismail (London, I889), p. I44, with A. E. P. Wiegall, A History of Events in Egypt from 1798 to I9I4 (London, I9I 5), p. I06.

${ }^{5}$ B. A. Temple and I. D. Skennerton, A Treatise on the British Military Martini (London, 1983), pp. 84 and III-II2.

${ }^{6}$ The competition attracted entries from the Winchester Repeating Rifle Company and E. Remington and Sons also: Hull, Providence Tool Co., pp. 20-2I; Achtermeier, Rhode Island., p. 39; and J. A. Grant, Rulers, Guns, and Money (New Haven RI, 2007), p. 22. A submission by the Birmingham Small Arms Company, presumably of a Martini-Henry pattern rifle, arrived too late for consideration as their local agent was 'acting for two firms in the United States and had deliberately held back B.S.A.'s entry in the hope that the order would go to one of the American companies, from which a larger commission could be expected': D. M. Ward, The Other Battle (Birmingham, I946), p. I6.

${ }^{7}$ Hull, Providence Tool Co., pp. 20-2I, and Achtermeier Rhode Island, 38, summarise the offer and the resulting contract.

${ }^{8}$ Achtermeier, Rhode Island, p. 43; H.Hintermeier, 'Türkische Peabody-Gewehre.
Umbau älterer türkischer Peabody-Martini auf die 7,65-mm-Mauser-Patrone', Deutsche Waffen Journal 37/4 (200I), pp. II8-I25: p. I2O.

9 As Note 7.

${ }^{10}$ As Note 7.

${ }^{\text {II }}$ The chequered butt plate found with the Martini-Henry Mk. I 'Second Pattern' was omitted from the sealed design of the MartiniHenry Mk.I 'Third Pattern' of I7 July I 874 , and the chequered thumb rest introduced after 2I March I87I, was vetoed on the 9 April I 874: Temple and Skennerton, British Military Martini, pp. 85 and II I, and 83 and 95 .

${ }^{\mathrm{I} 2}$ Achtermeier, Rhode Island, p. I I7.

${ }^{13}$ See, e.g., Hull, Providence Tool Co., 2 I-22.

${ }^{14}$ As Note 7.

${ }^{15}$ Temple and Skennerton, British Martini Henry, pp. 56, 64, 67-68, 83-85 and 96, for the debates over what bayonet to use with the Martini-Henry, concluding that regular infantry would use a bushed version of the Pattern I 853 socket bayonet, and mounted and regular field artillery units a sword bayonet: the bayonet bar for a sword bayonet appeared on all subsequent production versions for simplicity of manufacture, the socket fitting eventually being dispensed with on the Mk.V: ibid p. I46.

${ }^{16}$ Norton, American Inventions, p. 63; Achtermeier, Rhode Island, p. 40.

${ }^{17}$ Hull Providence Tool Co., p. 2I, and Achtermeier, Rhode Island, p. 4I, with E. A. Hull, 'Providence Tool Co. Bayonets', Journal of the American Society of Bayonet Collectors 2 (I989), 8-9.

${ }^{18}$ C. B. Norman, Armenia and the Campaign of I 877 (London I878), p. I84, commented on the Peabody-Martini Rifle that: 'I think the Providence Tool Company may be congratulated on the success of their contract, more especially when the treatment to which the arms are daily exposed is taken into consideration rarely cleaned, thrown down on rocks, piled carelessly, and unpiled violently; it, to me, is a simple marvel how the weapons stand it at all. I have constantly taken the Rifles out of men's hands and examined them, finding them in a condition that would drive the captain of a line regiment into an early grave'. The official Russian account of the campaign, as translated into German, noted that the weapon was used by some $70 \%$ of the Ottoman army: V. Grzesicki, and F. Wiedstruck, Der Russisch-türkische Krieg, I877-I878 auf der Balkan-Halbinsel (Wien, I902), p. 45.

I9 The only 'modern' work in English on the 'Plevna Delay' is R. Furneaux, The Siege of Plevna (London, I958), supplemented now by 
Q. Barry, War in the East (London, 2012) p.I54-I65, 263-288 and 35I-363. R. T. Trenk, 'The Plevna Delay', Men at Arms I9(4), I997, p.29-36, on-line at http://www.militaryrifles. com/turkey/plevna/theplevnadelay.html [accessed I 5 December 20I8], while broadly correct, incorrectly credits the Winchester Rifle for the 'Plevna Delay', a canard coined in P. Boudre, Russes et Turcs I (Paris, I878), p. 350, ignoring contrary contemporary accounts as, e.g. Osman Pacha, Mouzaffer Pacha and Talaat Bey, Défense de Plevna... (Paris, I878), 210, and W. W. von Herbert, The Defence of Plevna, I877, written by one who took part, end edn (London, I9II), p. 298.

${ }^{20} \mathrm{~S}$. Olgun, 'I9. Yüzyılın İkinci Yarısında Kalkandelen'de Silah Üretimi', in Osmanl Dönemi Balkan Şehirleri 2, ed. by T. Zafer and A. Temizer (İstanbul, 20I7) pp. 609-64I, 629. The devastating effect of the Peabody-Martini Rifle on the Russian and Romanian forces engaged in the siege of Plevna resulted in captured examples of the rifle being issued to one company in the Russian 63rd Regiment for an attack on one particularly well-entrenched Ottoman position at the decisive Battle of Shipka in January I876 (F. V. Greene, Russian Campaigns in Turkey 1877-78 (New York NY, I 879), pp. 353-354). Moreover-compliment of compliments-the Romanian government now commissioned the Österreichische Waffenfabriks-Gesellschaft at Steyr to make an exact copy in rifle and carbine form of the weapon, complete with chequered thumb rest, this becoming the Romanian Martini-Peabody Model I 879, which replaced-irony of ironiesthe Peabody Model I 868 Rifle with which the Romanian army was then equipped.

${ }^{2 \mathrm{I}}$ Hull, Providence Tool Co., p. 22; Achtermeier, Rhode Island, pp. 42-43.

${ }^{22} \mathrm{~N}$. Yorulmaz, Arming the Sultan (London, 20I4), pp. 97-98, notes Ottoman reports of 200 'Martini-Henry' Rifles produced there $3 \mathrm{I}$ May to 7 June I $88 \mathrm{I}$, and 840 , between 3 and I7 July. Some of the workmen were gunsmiths from the Kosovo and Tetovo region, famous for their 'clones' of military weapons: Olgun, Osmanlı Dönemi Balkan Şehirleri, 628-629.

${ }^{23}$ Achtermeier, Rhode Island, p. 43.

24 Yorulmaz, Arming the Sultan, p. I Io.

${ }^{25}$ Yorulmaz, Arming the Sultan, p. 33-34, with II3-II4, lists the other competitors, noting how the Birmingham Small Arms Company were on the verge of securing a contract for 400,000 Martini-Henry Rifles immediately before the competition, presumably the Mk.II's then in production (Temple and Skennerton,
British Martin-Henry, p. II9), only to lose out to German chicanery at the last minute.

${ }^{26} \mathrm{~W}$. Seel, 'Mauser-Gewehre unter dem Halbmond. Türken-Mauser: I. Folge', Deutsches Waffen-Journal, I7/6 (I98I), pp. 796-803, with Yorulmaz, Arming the Sultan, p. I 6 . For a detailed account of the various types of Mauser rifles and carbines employed by the Ottoman Empire and subsequently the Turkish Republic see R. W. D. Ball, Mauser Military Rifles of the World, 5th edn (Iola WI, 20II), pp. 374-388.

${ }^{27}$ Yorulmaz, Arming the Sultan, p. 98

${ }^{28}$ On I9 January I904, I63,354 of the 280,000 Model I 890 Rifles supplied to Constantinople were in store, the remainder distributed principally to the Third Army in the European Ottoman Empire, while of the I99,500 Model I893 Rifles, 35,295 were likewise in store: Yorulmaz, Arming the Sultan, pp. I29-130.

${ }^{29}$ M. Uyar and E. J. Erickson, A Military History of the Ottomans from Osman to Atatürk (Santa Barbara CA, 2009), p. 2 II.

${ }^{3 \circ} \mathrm{R}$. Bidwell, The Affairs of Kuwait I896-I905 II/6 (London, I97I), p. 86.

${ }^{3 \mathrm{I}}$ Hintermeier, 'Türkische Peabody-Gewehre', pp. I 99 and I22, and Yorulmaz, Arming the Sultan p. 128 .

${ }^{32}$ The steps leading up to and the conversion process itself are fully discussed by Hintermeier, 'Türkische Peabody-Gewehre', pp. I23-I24. The highest known conversion serial number is I99, 224-see Note 35. I thank John Sheehan for his patience in explaining what was involved.

${ }^{33}$ Experience soon showed that the rear hinge of the chamber needed to be provided with the strengthening plates visible in Figures 8-ro.

34 The Rumi calendar system was used from I 840 to I9I7/I9I 8 in place of the Islamic year system for ease of dealing with western countries, the Rumi year running from I3 March to I 2 March but according to the Julian rather than the Gregorian Calendar, to conform with the significant numbers of Greek and Orthodox Christians in the Ottoman territories. Thus an Ottoman financial year date of, e.g. I328 converts to I3 March I9I2 to I 2 March I9I3.

35 The lowest conversion serial number known to the author is 2337 on an rifle converted in 1327 (I9II/I9I2) in a private USA collection, the highest known with its date of conversion is I73,778 on one converted in I330 (I9I4/I9I5) in the Royal Armouries Museum Leeds (Accession number PR 6534), although as stated above, an example with the higher serialnumber of 199,224 has been recorded: this 
surfaced recently at an auction site in the USA, but no details are available regarding its conversion date. I am most grateful to Vernon Easley for this information. Somewhat confusingly the latest dated conversion, in a second private USA collection, is for $\mathrm{I} 33 \mathrm{I}$ (I9I5/I9I6) yet has the lower serial number of I64,236: thus the conversions were done and year-dated in one process, the serial numbers added in another.

${ }^{36}$ See, e.g. https://www.ottoman-uniforms.com/ I 9 I 2-till-I9I3-ottoman-uniforms-during-thebalkan-war/ [accessed I 5 December 20I8].

${ }^{37}$ H. B. Danışman, ed., Gallipoli I915: Bloody Ridge (Lone Pine) (İstanbul, 200I), p. 27.

${ }^{38} \mathrm{http}: / / w w w . l o c . g o v / p i c t u r e s / i t e m / 2007675298 /$ [accessed I5 December 20I8, see under troops at Katiah (Qatia)].

${ }^{39}$ Intelligence Section, Cairo, Handbook of the Turkish Army: Eighth Provisional Edition, February I9I6 (Imperial War Museum facsimile reprint I996), p. II.

$4^{\circ}$ There has been no dedicated analysis of this operation, but see, e.g. D. Storz, German Military Rifles: 88 and 9I Firearms (Vienna 2012), p. I47, for the shipment of a possible total of 142,600 Gew.88/05 in 1917 .

${ }^{4 \mathrm{I}}$ But note an order issued in June $\mathrm{I} 920$ at the start of the Turkish War of Independence that the various models of Martini (and other) rifles in private hands be reported to the regional Jandarma: see Murat Köylü, I919-I922 Döneminde Türk Ordusu Ikmal Sistemi Ile

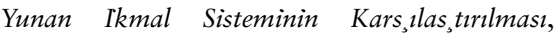
unpublished Ph.D thesis, Dokuz Eylül Ünïversitesï, Izmir, 2006, on line at: acikerisim. deu.edu.tr/xmlui/bitstream/handle/I 2345/6626/ 205975.pdf? [accessed I5 December 20I8], p. 44 .

${ }^{42}$ The emphasis here is on 'known examples', as remarkably few of the 400,000 PeabodyMartini sockets are known to have survived into the twenty-first century.

${ }^{43}$ Hull, 'Providence Tool Co. Bayonets', p. 9; Achtermeier Rhode Island, p. 38.

44 Norman, Armenia, p. I85.

45 For example, C. Gordon, Lessons on Hygiene and Surgery from the Franco-Prussian War (London, I 873), p. I05: 'The Prussians have only the triangular bayonet [as opposed to the sword bayonet], a weapon which produces wounds of much less severity than those by the French sword-bayonet', contra H. R. Wharton and B. F. Curtis, The Practice of Surgery: a Treatise on Surgery for the use of Practitioners and Students (Philadelphia PA, I898), p. $22 \mathrm{I}$ : 'Bayonet Wounds. -These wounds vary with the shape of the bayonet with which they are inflicted-either the triangular-shaped or the swordshaped bayonet. ... The wound produced by the sword bayonet is of the nature of an incised wound, and heals more promptly than that produced by the triangularshaped bayonet'.

${ }^{46}$ Cf. P. Kiesling, Bayonets of the World: the complete edition (Oosterbeek, 2008), p. 483, no. 362 , noting this might be an example of a bayonet used by the Romanian army with their Steyr-made Peabody-Martini Model I 879 Rifles, but the cumulative evidence is that these weapons were all fitted with a 'Gras'type bayonet: I am grateful to Andrej Blazicek for this information. The example in the Royal Armouries collections is PR.2732: I am most grateful to Lisa Traynor, Curator of Firearms, for showing me this specimen and supplying its accession number and a photograph.

${ }^{47}$ Hull, 'Providence Tool Co. Bayonets', p. 9.

${ }^{4}$ As according to the dicta of, for example, the Russian General A. Suvorov, e.g. 'The bullet is a mad thing; only the bayonet knows what fighting is about', and 'Attack with the cold steel! Push hard with the bayonet': C. Duffy, Russia's Military Way to the West (London, I982), I9I-I92. The attitude is expressed in several $19^{\text {th }}$ century training manuals, as, e.g. R. F. Burton, A Complete System of Bayonet Exercise (London, I 853), pp. 7 and Iо; T. H. Ruger, Extended Order Drill (Washington DC, I898), p. 73; A. Hutton, Fixed Bayonets (London, I890), pp. I25, and I3I-I32, the combination of artillery barrage and bayonet attack still being favoured in WWI despite the experiences of the RussoJapanese War.

${ }^{49}$ Hence the debate in 1870 over shortening the trials version of the Martini-Henry Mk.I Rifle to improve its balance from its original specified overall length of $5 \mathrm{I}$ inches to 47 inches, countered by the observation this would lessen the value of the weapon as a pike with bayonet fitted unless a longer bayonet was provided (i.e. the Elcho pattern: Temple and Skennerton, British Military Martini, pp. 64 and 67-68, with 208); and the eventual adoption of the Pattern 1876 bayonet with its blade length of 22.I 25 inches for use with the Martini-Henry: Skennerton and Richardson, British and Commonwealth Bayonets p. I4. I thank J. M. Ballard also for comments regarding his personal observations on the length relationship between bayonets and muskets and rifles during the eighteenth and nineteenth centuries. On the 
matter of the fixation with 'bayonet reach' we might note in passing how following on from the introduction in I886 of the French 'Lebel' rifle and its $2 \mathrm{I}$ inch $(52.7 \mathrm{~cm})$ long 'Rosalie' bayonet, the German $S .71 / 84$, the first true knife bayonet, with its 9.6 inch (25.5) long blade, then in use by active service units was withdrawn from these and replaced by the $S .7 I$ sword bayonet with a I 8.5 inch $(47 \mathrm{~cm})$ blade. Likewise general unease about the 'reach' of the SMLE Rifle with its original $\mathrm{I} 2$ inch $(30 \mathrm{~cm})$ Pattern 1903 bayonet compared to rifles and bayonets then in use by the continental powers (as noted by Hutton, Fixed Bayonets, p. v), led ultimately to the introduction of the longer Pattern I907, at around I6.88-I7.I3 inches $(42.9-43.5 \mathrm{~cm})$ : see, e.g. J. M. Ballard and J. Bennett, 'An Investigation of the Weights of Pattern 1907 Bayonets made in the UK around the First World War Period', Arms and Armour I $4 / 2$ (20I7), 206-222, 206-207.

${ }^{\circ}$ Hull Providence Tool Co., p. 2I, with Hull 'Providence Tool Co Bayonets', p. 9; Achtermeier, Rhode Island, p. 4I.

${ }^{51}$ Several photographs in the Abdul Hamid Collection in the Library of Congress, Washington DC, show members of the Ottoman army with the Peabody-Martini Rifle and fixed yataghan bayonet, e.g. http://www.loc.gov/ pictures/resource/cph.3 b28468/ [accessed I 5 December 20I 8].

$5^{2}$ For example, Herbert, Defence of Plevna, p. 23, 353 and 382; Norman, Armenia, p. 48 and I 85 ; and C. S. Ryan, Under the Red Crescent (New York, I897), p. 393.

${ }^{53}$ Hull Providence Tool Co, pp. 5-6.

${ }^{54}$ Hull. Providence Tool Co, p. 2 I.

55 See, e.g. Kiesling, Bayonets, p. 550, for the Model I 847, and 565, for the Model I 870 .

${ }^{56}$ Other individual letters recorded on the rifles but not on the bayonets are: 'D', 'L' and 'M', with ' $\mathrm{D}$ ' found on the cocking lever and seemingly nowhere else.

57 See R. Bayles, ed., History of Providence County, Rhode Island, 2 (New York, I89I), p. 435.

${ }^{58}$ For example, G. Yaşar, Askeri Müze Yată̆an Koleksiyon (İstanbul, 2009), 20. I am grateful to Eda Doğa Aras for supplying this reference.

59 Note, for example, the decision of the British Army in 1874 that infantry units supplied with the Martini-Henry be given a Pattern I 853 socket bayonet with a bushed socket while field and horse artillery units would carry an Elcho Pattern sword bayonet: see, e.g. Temple and Skennerton, British Military Martini, pp. 83-85, with 96 and II2, with Skennerton and Richardson, British and Commonwealth Bayonets, p. I42. For ease of manufacture, all Martini-Henry Rifles were provided with the appropriate fittings for use with either a sword or a socket bayonet until I 887 , when the socket fitting was dropped with the introduction of the Mk.IV: Temple and Skennerton, ibid, p. I46, with Skennerton and Richardson, ibid, pp. I60-I62.

${ }^{60}$ Norman, Armenia, p.I85. I am grateful to Henry Yallop for seeking clarification on the nature of these Ottoman Tallia units and so correcting my own initial impression these were mounted infantry.

${ }^{6 \mathrm{I}}$ Information from J. P. Sheehan.

${ }^{62}$ Hintermeier, 'Türkische Peabody-Gewehre.', p. I24.

${ }^{63}$ The matter of how bayonet length affected rifle balance was under comment from at least I 845 : see, e.g. 'F.G', 'Range of Firearms, the Swordbayonet, \&c.', Coburn's United Service Magazine and Naval and Military Journal Part I for $I_{845}$ (Vol. 45), pp. 598-599. It was discussed also by the British Small Arms Committee on 28 May, I869, which concluded that while a Martin-Henry Rifle fitted with an 'ordinary [i.e. triangular] bayonet fixed' resulted in a pike-like weapon three inches shorter than the Snider rifle with fitted bayonet, 'the other advantages [i.e. weight and ease of use in close combat] it gave were felt to outweigh the disadvantages': Temple and Skennerton, British Martini-Henry, p. 56. This view was maintained after the introduction of the short Pattern I 888 knife bayonet, as e.g. A. Hutton, Fixed Bayonets, pp. v, I25, and I3I-I32; also by the Earl of Donoughmore in the House of Lords on the 23 February, I903, discussing the introduction of the SMLE Mk.I Rifle and its Pattern 1903 bayonet: Hansard House of Lords, vol. I4I, cc I055-I057. https://api.parliament. uk/historic-hansard/lords/I905/feb/23/rapid-fire [accessed I 5 December 20I8].

${ }^{64}$ Reproduced also in A. F. Bilkan and Ö. Çakır, Harp Mecmuası (İstanbul, 2004), p. 90, Figure I22.

${ }^{65}$ Information from Dr. C. Flaherty.

${ }^{66}$ Norman, Armenia, p. I 85. 


\section{Notes on contributor}

Julian Bennett is a Fellow of the Society of Antiquaries of London. Having received his BA in Archaeology at the University of Durham, UK, he was subsequently awarded a PhD by the University of Newcastle upon Tyne, UK, for his research on Hadrian's Wall. Currently an Associate Professor in the Department of Archaeology at İhsan Doğramacı Bilkent University in Ankara, Turkey, he combines his studies in Roman archaeology with research into the bayonets and other artefacts of the Great War.

Correspondence to: Julian Bennett. Email: bennett@bilkent.edu.tr. 